Research Article

\title{
Genotypic Variability in Some Morpho-Physiological Traits in Different Environments and Their Relationship with Cassava (Manihot esculenta Crantz) Root Yield
}

\author{
Joseph Adjebeng-Danquah $\mathbb{D}^{1},{ }^{1}$ Isaac Kwadwo Asante, ${ }^{2}$ Joseph Manu-Aduening, ${ }^{3}$ \\ Richard Yaw Agyare, ${ }^{1}$ Vernon Edward Gracen, ${ }^{2}$ and Samuel Kwame Offei ${ }^{2}$ \\ ${ }^{1}$ CSIR-Savanna Agricultural Research Institute, Nyankpala, P.O. Box TL 52, Tamale, Ghana \\ ${ }^{2}$ West Africa Centre Crop Improvement (WACCI)/University of Ghana, Legon, Ghana \\ ${ }^{3}$ CSIR-Crops Research Institute, Fumesua, P.O. Box 3785, Kumasi, Ghana
}

Correspondence should be addressed to Joseph Adjebeng-Danquah; barchus2003@yahoo.com

Received 27 December 2019; Revised 8 June 2020; Accepted 23 June 2020; Published 26 July 2020

Academic Editor: Cristina Patan

Copyright (c) 2020 Joseph Adjebeng-Danquah et al. This is an open access article distributed under the Creative Commons Attribution License, which permits unrestricted use, distribution, and reproduction in any medium, provided the original work is properly cited.

\begin{abstract}
Cassava root yield under diverse environments is influenced by morpho-physiological traits that are in turn influenced by genotype, environment, and genotype $\times$ environment interaction (GEI). Most GEI analyses in cassava have been limited to root yield with less emphasis on stability of other yield-related traits. This study was carried out to assess the effect of GEI on some morpho-physiological traits in cassava and key traits that are useful for selection in different environments. The study utilized 20 cassava genotypes evaluated in six environments, namely, Fumesua 2013 and 2014, Nyankpala 2013 and 2014 (irrigation), and Nyankpala 2013 and 2014 (no irrigation). The genotypes were arranged in a randomized complete block design (RCBD) with three replications and assessed for a number of morpho-physiological traits, root yield and yield components. The data were subjected to analysis of variance using SAS statistical package. Subsequently, the GGE biplot was used to carry out genotype $\times$ environment, genotype $\times$ trait, and environment $\times$ trait interaction analyses to determine the specificity of genotypic performance and traits linked to particular environments. The results indicated significant $(P<0.05)$ GEI effect on all traits except leaf temperature. The genotype $\times$ trait biplot analysis revealed closely related traits and those associated with root yield and genotypes that show weakness in these traits. Both environment $\times$ trait biplot and principal component analyses identified traits with higher discriminatory power among genotypes in various environments particularly in the dry environments. These can be used as secondary traits to select drought-tolerant genotypes. From this study, the GGE biplot was useful in identifying traits associated with specific genotypes in different environments to aid in selection. Moderate broad-sense heritability estimates werefound for storage root yield, harvest index, plant height, ratio of storage rootlength to girth, and cassava mosaic disease score indicating that progresscan be made through selection for these traits.
\end{abstract}

\section{Introduction}

Cassava (Manihot esculenta Crantz) serves as a staple food for millions of people in sub-Saharan Africa because it provides a cheap source of carbohydrate per unit area. It is widely cultivated in most farming systems in Africa due to its ability to give appreciable yields in marginal ecologies where other crops will fail [1]. However, severe yield losses can occur in unimproved genotypes that are susceptible to various biotic and abiotic constraints present in these environments [2,3]. Depending on the cultivar, yield losses in storage root can be as high as $80 \%$ in drought-prone or moisture-stressed environments [4]. This means that genotypes vary in their requirements for nutrients and other resources in the environment and may elicit different responses in different environments [5].

Cassava's improved performance in harsh environments is due to different adaptive physiological mechanisms that 
enable the crop to survive under adverse environmental conditions. For instance, drought tolerance in cassava is based on drought avoidance through partial stomatal closure which result in moisture conservation $[4,6]$. Other studies have also indicated abscisic acid accumulation, variation in root development, carbon isotope discrimination, and proline accumulation which regulate the crop's differential performance under water-limited conditions [6-9]. On the other hand, the mechanisms underlying these traits are regulated by several genes within the cassava genome which can be targeted in breeding to select improved cassava genotypes for drought-prone ecologies [10-12]. For instance, 10 candidate genes have been found to be associated with drought tolerance mechanisms in cassava which are upregulated under stress to mitigate the negative effects of moisture stress [6]. However, the phenotypic expression of these genes is influenced by the environment and genotype $\mathrm{x}$ environment interaction (GEI) leading to crossover performances in different environments $[13,14]$.

Progress in direct selection for yield under moisturestressed environments has been slow due to its low heritability, polygenic control, epistasis, and GEI [15]. Indirect selection criteria such as the use of physiological traits closely associated with yield in stress environment are very effective for improving yield under abiotic stress conditions [16]. Several studies have reported yield improvement under drought stress in various crops using indirect selection for traits such as anthesis-silking interval in maize [17], abscisic acid accumulation, leaf retention, stem starch accumulation, stomatal conductance, and canopy temperature in cassava $[18,19]$. The suitability of these secondary traits as indirect selection indices depends on their consistency and association with improved yield in different environments [20]. In the absence of significant GEI, the selection of genotypes based on these traits in one environment will accurately predict the performance of the genotypes across different production environments. However, most traits of agronomic importance are influenced by GEI which confounds selection for several environments due to reranking of genotypic performance [21-23].

The analysis of GEI effects in cassava in multienvironment trials is often limited to only yield without much consideration to the secondary traits though several traits are measured $[24,25]$. The associations among these traits and relationships with yield are mostly determined using simple correlation analysis, path coefficient analysis, genotypic correlation analysis, and regression analysis which may sometimes result in inefficiencies and portray slow progress as a result of negative interactions between traits of interest and other traits [26-28]. Moreover, there is limited information on the effect of GEI on secondary traits such as stomatal conductance, leaf temperature, and other morphological traits as well as their relationships with root yield in diverse ecologies. Besides GEI, information on the genetic parameters and heritability of traits allows the discrimination between genetic and environmental factors in order to improve selection efficiency and contribute to gains in selection [29]. Apart from the nature and magnitude of genetic variability within a population, the success of plant breeding depends largely on the heritability of the traits concerned [30]. Heritability which is the proportion of phenotypic variation in a population due to genetic differences helps to predict the response to selection and choose the appropriate traits for selection [31]. Selection for highly heritable traits often leads to faster and increased gains especially when they positively correlate with other traits of economic importance and as such could be exploited by plant breeders for progress [32].

Though statistical parameters such as mean, ranges, and variances have been useful in providing diversity information on traits among genotypes, they do not enable the simultaneous comparisons of genotypes and plant attributes [33]. Multivariate statistical methods such as principal component (PC) analysis and cluster analysis that permit characterization and grouping of genotypes based on multiple traits can be very useful in breeding programmes [34]. The GGE biplot, though mostly used in the analysis of GEI effect on yield, can also be used in multivariate analysis of these secondary traits and assess their relationships with root yield in cassava $[24,25]$. Studies in other crops have indicated that the GGE biplot can be used for visual assessment of the relationships among traits, relationships of different traits with different environments, and traits that are associated with specific genotypes. This can help to identify negatively or positively correlated traits and also identify the weaknesses and strengths of different genotypes based on specific traits [35]. This implies that genotype $\times$ trait analysis and environment $\times$ trait analysis will offer a better understanding of the these physiological traits underlying the mechanism of cassava's improved yield under different growing conditions and the associated secondary traits for adaptation and productivity [36]. The objectives of this study were to (1) determine the genotype $\times$ environment interaction (GEI) effect on physiological traits underlying the improved performance of cassava under different growing environments; (2) identify the key traits accounting for variations under different environments as well as the relationship between these physiological traits and storage root yield; and (3) assess broadsense heritability of different physiological traits under different environments.

\section{Materials and Methods}

2.1. The Study Sites. The study was carried out from 2012 to 2014 at two sites: CSIR-Savanna Agricultural Research Institute, located at Nyankpala $\left(9^{\circ} 25^{\prime} \mathrm{N}, 0^{\circ} 58^{\prime} \mathrm{W}\right)$ in the Guinea Savannah Zone and the Crops Research Institute (CSIR$\mathrm{CRI})$, located at Fumesua $\left(6^{\circ} 41^{\prime} \mathrm{N}, 1^{\circ} 28^{\prime} \mathrm{W}\right)$ in the Forest Zone of Ghana. The Guinea Savannah Zone is characterized by high temperature and low humidity during most parts of the year. The rainfall pattern is monomodal and erratic with an annual mean of $1100 \mathrm{~mm}$ which mostly begins in AprilMay and ends in October. The post-rainy season is also characterized by a long dry season often lasting four to five months [37]. In each of the two seasons, two trials were conducted at Nyankpala: one under irrigation and another under no irrigation. The site at CSIR-CRI is characterized by a bimodal rainfall pattern: major and minor rainy seasons. 
The major rainy season begins in February and ends in August followed by the minor season which begins in September and ends in November. One trial was conducted in each of the two years at CSIR-CRI, Fumesua, in the humid ecology to serve as the optimum environment for the assessment of high yield potential. The combination of the two sites, two irrigation regimens, and two years gave six environments, namely, no irrigation-2013 (NIR13), no irrigation-2014 (NIR14), irrigation-2013 (IRR13), irrigation2014 (IRR14), Fumesua-2013 (FUM13), and Fumesua-2014 (FUM14).

2.2. Genotypes and Experimental Design. The experimental materials consisted of twenty contrasting cassava genotypes (Table 1) that were selected from an earlier study [7]. These genotypes were made up of six local landraces collected from farmers' fields, seven drought-tolerant genotypes obtained from the International Institute of Tropical Agriculture (IITA), and seven genotypes collected from the International Centre for Tropical Agriculture (CIAT), Columbia. The genotypes were arranged in a randomized complete block design with three replications under each growing condition. A plot consisted of four rows with ten plants in a row giving a population of 40 plants in each plot. Data were collected on the two central rows considering the outer rows as border plants.

2.3. Land Preparation and Planting. At each site, the land was ploughed and harrowed before planting. In the case of the trials at CSIR-SARI Nyankpala, the cuttings were planted on ridges spaced at one metre apart and one metre between rows to facilitate the laying of drip irrigation lines. The trials at CSIR-CRI, Fumesua, were planted on the flat with no ridging (cassava cultivation in the forest ecology is done on the flat with no ridging, so this was considered as part of the inherent conditions pertaining in that particular environment). Planting was done using mature cassava cuttings measuring $25-30 \mathrm{~cm}$ by burying two-third on top of the ridges or in holes dug on the flat as the case may be. The cuttings were slanted at an angle of $45^{\circ}$ to the ground surface [38]. Weeds were controlled as and when necessary. Reshaping of ridges was done to prevent exposure of the roots.

2.4. Soil Sampling. Before planting, soil samples were taken from depths of $0-15 \mathrm{~cm}$ and $15-30 \mathrm{~cm}$ within each replication. The top and subsoils were then analysed for the $\mathrm{pH}$, percentage nitrogen, potassium, phosphorus, organic carbon, calcium, magnesium, and cation exchange capacity. The particles were also analysed for percentage sand, silt, and clay which was used to compute the textural class. These analyses were performed using the appropriate standard protocols.

2.5. Irrigation Regimen at Nyankpala. At the onset of the dry season (end of November), supplementary irrigation was applied using a drip irrigation system. The irrigation commenced when visible signs of moisture stress begun to appear on the plants and evaporation exceeded precipitation. No irrigation was applied to drought-stressed plots. Drip laterals were laid at a spacing of one metre apart. Drip holes, spaced at $30 \mathrm{~cm}$ interval on each line, had a discharge capacity of $1.61 \mathrm{hr}^{-1}$. This gave a discharge rate of 5.33 litres $^{-1} \mathrm{~m}^{-2} \mathrm{hr}^{-1}$. Water was supplied twice a week for four hours each day until May when the rains stabilized.

\subsection{Data Collection}

2.6.1. Growth Parameters. Data were recorded on growth parameters beginning at three months after planting. These included plant height $(\mathrm{cm})$, number of leaves per plant, and number of branches per plant.

2.6.2. Stomatal Conductance and Leaf Temperature. Stomatal conductance $\left(\mathrm{mmol}^{-2} \mathrm{~s}^{-\mathbf{1}}\right)$ and leaf temperature $\left({ }^{\circ} \mathrm{C}\right)$ were simultaneously measured using a leaf porometer (Decagon services, USA). Stomatal conductance is the measure of the rate of passage of carbon dioxide $\left(\mathrm{CO}_{2}\right)$ or water vapour through the stomata of the leaf [39]. Data collection commenced at four months after planting. The readings were taken on two plants from each plot.

2.6.3. Fresh Root Yield $\left(t h a^{-1}\right)$ and Yield Components. Harvesting was done at 12 months after planting. Eight plants from the two inner rows were sampled for yield determination. Five roots were selected from each plant for root dimensions' measurements, measured from one tip to the other using a tape measure to determine root length $(\mathrm{cm})$. Root girth $(\mathrm{cm})$ was also determined by measuring the widest portion of the same roots using vernier callipers. The ratio of storage root length:girth was then estimated. Number of storage roots per plant was also recorded. Harvest index was also estimated as the ratio of storage root weight to total biomass weight.

2.6.4. Assessment of Cassava Mosaic Disease (CMD) Severity. This was scored using a scale of $1-5$ where $1=$ no symptom and $5=$ highly diseased plants [40].

\subsection{Data Analysis}

2.7.1. Analysis of Variance. The data were subjected to analysis of variance using the PROC GLM of the Statistical Analysis System (SAS) version 9.2 [41] to determine the significance of the main effects and interactions. Combined analyses of variance for the physiological parameters, growth parameters, and root yield and yield components from different environments were done. In this case, a combination of three environments (irrigation, no irrigation, and Fumesua) and two growing seasons (2013 and 2014) were used giving a total of six environments. Genotypic $\left(\sigma_{g}^{2}\right)$, genotype $\times$ environment $\left(\sigma_{g e}^{2}\right)$, environmental $\left(\sigma_{e}^{2}\right)$, and 
TABLE 1: List of cassava genotypes used in the study.

\begin{tabular}{|c|c|c|c|c|c|}
\hline Genotype & Source & Attribute & Genotype & Source & Attribute \\
\hline ATR 002 & Local & $\begin{array}{l}\text { Moderate root yield, drought } \\
\text { susceptible }\end{array}$ & $00 / 0203$ & IITA & $\begin{array}{c}\text { High root yield, drought tolerant, profuse } \\
\text { branching }\end{array}$ \\
\hline ATR 007 & Local & $\begin{array}{l}\text { Moderate root yield, drought } \\
\text { susceptible }\end{array}$ & $96 / 1708$ & IITA & Moderate root yield, moderate drought tolerance \\
\hline NWA 004 & Local & High yield, good plant type & I91934 & IITA & $\begin{array}{c}\text { High root yield, moderate drought tolerance, } \\
\text { early branching }\end{array}$ \\
\hline PONTISANGE* & Local & $\begin{array}{l}\text { Moderate root yield, drought } \\
\text { susceptible }\end{array}$ & CTSIA 45 & CIAT & $\begin{array}{c}\text { Tall plant stature, moderate root yield, high leaf } \\
\text { production }\end{array}$ \\
\hline BIABASSE* & Local & $\begin{array}{l}\text { Moderate root yield, drought } \\
\text { susceptible, early branching }\end{array}$ & CTSIA 48 & CIAT & $\begin{array}{l}\text { Tall plant stature, moderate root yield, moderate } \\
\text { drought tolerance, high leaf production }\end{array}$ \\
\hline UCC2001/449 & Local & $\begin{array}{l}\text { High yield, high leaf produ } \\
\text { profuse branching, drought }\end{array}$ & CTSIA 65 & CIAT & $\begin{array}{l}\text { Tall plant stature but low root yield, low leaf } \\
\text { production, moderate tolerance to drought }\end{array}$ \\
\hline TME 419 & IITA & $\begin{array}{l}\text { Late branching, drou } \\
\text { moderately high }\end{array}$ & CTSIA 72 & CIAT & $\begin{array}{c}\text { Tall plant stature, moderate root yield, moderate } \\
\text { drought tolerance }\end{array}$ \\
\hline TME 435 & IITA & $\begin{array}{l}\text { Late branching, drought tolerant, } \\
\text { moderately high yielding }\end{array}$ & $\begin{array}{c}\text { CTSIA } \\
112\end{array}$ & CIAT & $\begin{array}{l}\text { Tall plant stature, moderate root yield, drought } \\
\text { tolerant, high leaf production, profuse branching }\end{array}$ \\
\hline $96 / 409$ & IITA & $\begin{array}{c}\text { Profuse branching, early branching, } \\
\text { drought tolerant }\end{array}$ & $\begin{array}{l}\text { CTSIA } \\
230\end{array}$ & CIAT & $\begin{array}{c}\text { Tall plant stature, drought tolerant, moderate root } \\
\text { yield }\end{array}$ \\
\hline MM96/1751 & IITA & $\begin{array}{l}\text { Late branching, drought tolerant, } \\
\text { moderate root yield, tolerant to mosaic }\end{array}$ & $\begin{array}{c}\text { CTSIA } \\
110\end{array}$ & CIAT & $\begin{array}{l}\text { Tall plant stature, high leaf production, moderate } \\
\text { root yield, drought tolerant, profuse branching }\end{array}$ \\
\hline
\end{tabular}

${ }^{*}$ Checks (local farmer preferred varieties).

phenotypic $\left(\sigma_{p}^{2}\right)$ variances were computed using the expected mean squares from the analysis of variance table [23].

Broad-sense heritability $(H)$, phenotypic coefficient of variation $(P C V)$, and genotypic coefficient of variation $(G C V)$ were estimated as follows [20]:

$$
H^{2}=\frac{\sigma_{g}^{2}}{\sigma_{p}^{2}}
$$

where $\sigma_{g}^{2}=$ genotypic variance and $\sigma_{p}^{2}=$ phenotypic variance.

$$
\sigma_{p}^{2}=\sigma_{g}^{2}+\frac{\sigma_{g e}^{2}}{E}+\frac{\sigma_{e}^{2}}{E R},
$$

where $\sigma_{g}^{2}=$ genotypic variance, $\sigma_{g e}^{2}=$ genotype $\times$ environment variance, $\sigma_{e}^{2}=$ environmental variance, $E=$ number of environments, and $R=$ number of replications.

Genotypic coefficient of variation $(G C V)$ and phenotypic coefficient of variation (PCV) were estimated as follows [42]:

$$
\begin{aligned}
& \operatorname{GCV}(\%)=\frac{\sqrt{\sigma_{g}^{2}}}{X} \times 100, \\
& \operatorname{PCV}(\%)=\frac{\sqrt{\sigma_{p}^{2}}}{X} \times 100,
\end{aligned}
$$

where $X=$ grand mean.

Expected genetic advance, $G_{A}$, was calculated as

$$
G_{A}=(K) \sigma_{A} H^{2}
$$

where $G_{A}=$ expected genetic advance, $K=$ selection differential (2.06 at $5 \%$ selection intensity), and $\sigma_{A}=$ phenotypic standard deviation.
Genetic advance as a percentage of mean (GAM) was also estimated using the formula:

$$
G A M=\left(\frac{G_{A}}{X}\right) \times 100 .
$$

2.7.2. Genotype and Genotype $\times$ Environment (GGE) Biplot Analyses. The GGE biplot was used to obtain information on the yield performance and stability of the genotypes. Furthermore, genotype by trait biplot analysis and environment by trait analysis were performed to determine the association between genotypes and specific trait or group of traits. Environment by trait analysis was also performed to determine which traits are more discriminatory among genotypes in specific environments. This was carried out using the $\mathrm{R}$ software package [43]. The model for the GGE biplot is given as

$$
Y_{g e}=\mu+\beta_{e}+\sum_{n}^{N} \lambda_{n} \gamma_{g n} \delta_{e n}+\varepsilon_{g e},
$$

where $Y_{g e}=$ trait value of genotype $g$ in environment $e$, $\mu=$ grand mean, $\beta_{e}=$ environment deviation from the grand mean, $N=$ number of interaction principal components (IPC) considered, $\lambda_{n}=$ singular value for the IPC $n, \gamma_{g n}=$ the element of eigenvector for genotype $g$ and IPC $n, \delta_{e n}=$ the element of eigenvector for environment $e$ and IPC $n$, and $\varepsilon_{g e}=$ random error [44].

\section{Results}

3.1. Weather Conditions in Different Environments. The environments differed in mean monthly rainfall amounts, 
TABLE 2: Average monthly rainfall, irrigation water supplied, temperature, and relative humidity.

\begin{tabular}{lcccc}
\hline Environment & Mean monthly rainfall $(\mathrm{mm})$ & Irrigation water per month $(\mathrm{mm})$ & Mean temperature $\left({ }^{\circ} \mathrm{C}\right)$ & Relative humidity $(\%)$ \\
\hline NIR13 & 82.64 & - & 28.29 & 68.68 \\
NIR14 & 98.42 & - & 28.71 & 68.5 \\
IRR13 & 82.64 & 162.53 & 28.29 & 68.68 \\
IRR14 & 98.42 & 170.66 & 28.71 & 68.5 \\
FUM13 & 95.59 & - & 27.3 & 75.4 \\
FUM14 & 135.00 & - & 25.8 & 81.3 \\
\hline
\end{tabular}

NIR13 = Nyankpala under no irrigation in 2013, NIR14= Nyankpala under no irrigation in 2014, IRR13= Nyankpala under irrigation in 2013, IRR14 = Nyankpala under irrigation in 2014, FUM13 = Fumesua in 2013, and FUM14 = Fumesua in 2014.

mean temperature, and relative humidity (Table 2). In addition to the monthly rainfall, a monthly average of $162.53 \mathrm{~mm}$ of irrigation water was supplied to the irrigated plots in 2013, whereas a monthly amount of $170.66 \mathrm{~mm}$ was applied in 2014. The mean monthly rainfall for Fumesua in $2014\left(135.00 \mathrm{~mm} \mathrm{month}{ }^{-1}\right)$ was higher than what was recorded in $2013\left(95.59 \mathrm{~mm} \mathrm{month}^{-1}\right)$ as well as the other environments $\quad($ NIR13 $=82.64$; $\quad$ NIR14=98.42). Mean monthly temperature recordings at Nyankpala under both irrigation (IRR13 and IRR14) and no irrigation (NIR13 and NIR14, respectively) were also higher than Fumesua in both years. Fumesua (FUM13 and FUM14) in both years was more humid than the conditions at Nyankpala.

\subsection{Soil Physical and Chemical Characteristics of the Exper-} imental Sites. Results from soil physical and chemical analyses from different environments are presented in Table 3. The results indicated that the soils from Fumesua in 2013 and 2014 were higher in most of the major elements than the soils from the irrigated and no irrigation environments at Nyankpala in both years. The soil texture varied from loamy sand at Fumesua in 2013 and 2014 to sandy loam for the Nyankpala trials in 2013 and silty loam for the Nyankpala trials in 2014.

\subsection{Analysis of Variance for Physiological, Growth, and Yield} Traits. Analysis of variance for the individual environments is presented in Tables 4 and 5. At Fumesua (2013), highly significant $(P<0.001)$ genotypic differences were observed for all traits except leaf temperature and storage root length (Table 4). In the 2014 trial at Fumesua, above ground biomass yield, cassava mosaic disease score, harvest index, and plant height were highly significant $(P<0.001)$ whilst number of branches per plant, storage root yield, and stomatal conductance were very significant $(P<0.01)$ with storage root length: girth ratio, number of leaves per plant storage root girth, and number of roots per plant being significant $(P<0.05)$.

At Nyankpala under irrigation (2013), significant $(P<0.05)$ differences were observed for all traits except leaf temperature and number of roots per plant (Table 5). Under irrigation in 2014, significant genotypic differences were again observed for all traits except leaf temperature and stomatal conductance. Significant genotypic differences were also observed under no irrigation in 2013 for all traits except leaf temperature, number of leaves per plant, and storage root length. Apart from above ground biomass yield, leaf temperature, number of leaves per plant, and stomatal conductance, all the growth, physiological, and yield parameters studied were significant under no irrigation in 2014. Irrespective of the environment, there was not significant genotypic difference for leaf temperature.

\subsection{Combined Analysis of Variance of Root Yield and Other} Traits of 20 Cassava Genotypes. Mean squares from the combined analysis of variance across environments indicated various levels of significance for the main effects and interaction for different traits (Table 6). Genotype by environment interaction (GEI) effect was highly significant $(P<0.001)$ for number of branches per plant, cassava mosaic disease $(\mathrm{CMD})$ score, above ground biomass yield $\left(\right.$ tha $\left.^{-1}\right)$, and storage root yield $\left(\right.$ tha $\left.^{-1}\right)$, very significant $(P<0.01)$ for stomatal conductance, number of leaves per plant, and storage root length to girth ratio (L: G ratio), and significant $(P<0.05)$ for storage root girth and storage root length. However, GEI effect on leaf temperature was not significant $(P>0.05)$. The main effect of environment was also highly significant $(P<0.001)$ for all traits. Genotype main effect was also significant for all the traits except leaf temperature $(P>0.05)$.

3.5. Variance Components, Estimates of Genetic Parameters, Broad-Sense Heritability, and Genetic Advance for Root Yield and Other Traits of 20 Cassava Genotypes. Variance components, heritability, and genotypic and phenotypic coefficients of variation are presented in Table 7. All traits had higher genotypic variances than their interaction variances. Apart from plant height, cassava mosaic disease (CMD) score, harvest index, and $\mathrm{L}: \mathrm{G}$ ratio, the error variances of the other traits were higher than their corresponding genotypic and $G \times E$ variances. Broad-sense heritability estimates varied from the lowest of $9.45 \%$ to the highest of $53.42 \%$ for leaf temperature and CMD score, respectively. Only plant height, CMD score, and L: G ratio had broadsense heritability above $50 \%$. The rest of the traits had low heritability estimates.

Genotypic coefficient of variation ranged from $0.89 \%$ (leaf temperature) to $39.86 \%$ (number of branches per plant). Phenotypic coefficient of variation also varied from $2.9 \%$ for leaf temperature to $65.73 \%$ for number of branches per plant. The magnitude of the difference between the phenotypic and genotypic coefficient of variation was 
TABLE 3: Soil physical and chemical characteristics at the study sites in 2013 and 2014.

\begin{tabular}{|c|c|c|c|c|c|c|}
\hline \multirow{3}{*}{ Soil parameters } & \multicolumn{6}{|c|}{ Environments } \\
\hline & \multicolumn{2}{|c|}{ Fumesua } & \multicolumn{2}{|c|}{ Irrigated } & \multicolumn{2}{|c|}{ Nonirrigated } \\
\hline & 2013 & 2014 & 2013 & 2014 & 2013 & 2014 \\
\hline $\mathrm{pH}$ & 5.75 & 4.58 & 4.67 & 4.30 & 4.65 & 4.71 \\
\hline$\% \mathrm{~N}$ & 0.08 & 0.09 & 0.06 & 0.03 & 0.06 & 0.03 \\
\hline $\mathrm{P}(\mathrm{mg} / \mathrm{kg})$ & 3.37 & 4.16 & 2.04 & 2.74 & 2.77 & 2.55 \\
\hline $\mathrm{K}(\mathrm{mg} / \mathrm{kg})$ & 108.83 & 79.50 & 62.33 & 39.33 & 61.17 & 41.00 \\
\hline$\% \mathrm{OC}$ & 1.59 & 1.13 & 0.60 & 0.39 & 0.48 & 0.38 \\
\hline $\mathrm{Ca}(\mathrm{cmol} / \mathrm{kg})$ & 163.50 & 298.70 & 99.00 & 270.80 & 102.00 & 267.00 \\
\hline $\mathrm{Mg}(\mathrm{cmol} / \mathrm{kg})$ & 95.00 & 110.72 & 50.50 & 68.46 & 44.00 & 72.71 \\
\hline $\mathrm{CEC}(\mathrm{cmol} / \mathrm{kg})$ & 12.81 & 12.81 & 8.25 & 5.82 & 7.69 & 6.53 \\
\hline Texture & Loamy sand & Loamy sand & Sandy loam & Silty loam & Sandy loam & Silty loam \\
\hline
\end{tabular}

$\% \mathrm{~N}=$ percentage nitrogen (\%), $\mathrm{P}=$ phosphorus $\left(\mathrm{mg} \mathrm{kg}^{-1}\right), \mathrm{K}=$ potassium $\left(\mathrm{mg} \mathrm{kg}^{-1}\right), \% \mathrm{OC}=$ organic carbon $(\%), \mathrm{Ca}=\mathrm{calcium}\left(\mathrm{cmol} \mathrm{kg}^{-1}\right), \mathrm{Mg}=\mathrm{magnesium}$ $\left(\mathrm{cmol} \mathrm{kg}{ }^{-1}\right)$, and $\mathrm{CEC}=$ cation exchange capacity $\left(\mathrm{cmol} \mathrm{kg}^{-1}\right)$.

highest for leaf temperature and the lowest for $\mathrm{L}: \mathrm{G}$ ratio as indicated by their ratios. The ratio of $P C V: G C V$ for leaf temperature was three times compared with $\mathrm{L}: \mathrm{G}$ ratio (1.40). The $P C V: G C V$ ratio for stomatal conductance, number of leaves per plant, and number of roots per plant was two times or greater.

Genetic advance considering a selection intensity of 5\% indicated that stomatal conductance can be increased by $19.23 \mathrm{mmol}^{-2} \mathrm{~s}^{-1}$, leaf temperature can be reduced by $0.32^{\circ} \mathrm{C}$, plant height can be increased by $70.89 \mathrm{~cm}$, and number of leaves can be increased by 65 leaves per plant, whilst CMD score can also be reduced by 1.08 . Above ground biomass can be increased by $5.78 \mathrm{tha}^{-1}$ and storage root yield can be increased by $10.34 \mathrm{tha}^{-1}$, with root girth and length being increased by $1.25 \mathrm{~cm}$ and $3.35 \mathrm{~cm}$, respectively. Storage root number is also expected to be increased by 1.03 and harvest index can be increased by 0.11 , whilst $L: G$ ratio can be increased by 1.44 .

Genetic advance as percentage of mean (GAM) also indicated that the most remarkable improvement $(64.81 \%)$ can be realized in CMD score. The lowest improvement is expected in reduction in leaf temperature $(0.92 \%)$, whilst the mean number of leaves per plant, storage root yield, plant height, and above ground biomass yield are expected to be increased by $30 \%$ or more. Less improvement is also expected in storage root length, root number per plant, L:G ratio, harvest index, root length, and number of branches per plant.

3.6. Average Performance of Genotypes for 13 Traits from Six Environments. Average performance of genotypes for the 13 traits the six environments are presented in Table 8. Above ground biomass yield ranged between $9.82 \mathrm{tha}^{-1}$ and $26.06 \mathrm{tha}^{-1}$ for CTSIA 72 and 96/409, respectively, with a mean of $17.06 \mathrm{tha}^{-1}$. Number of branches per plant ranged between 3.47 (MM96/1751) and 19.71 (00/0203). MM96/ 1751 had the lowest cassava mosaic disease (CMD) score (1.00) with genotype CTSIA 230 having the highest CMD score (2.53) across environments. Genotype CTSIA 65 produced the tallest plants, $249.67 \mathrm{~cm}$ with $00 / 0203$ having the shortest plant height across environments $(137.73 \mathrm{~cm})$. The highest number of leaves per plant at harvest was recorded on CTSIA 110 (233.43 leaves per plant) with MM96/1751 having the least number of leaves (63.42). CTSIA 112 had the highest average stomatal conductance reading $\left(204.40 \mathrm{mmol}^{-2} \mathrm{~s}^{-1}\right)$ with $96 / 409$ having the lowest average stomatal conductance $\left(152.27 \mathrm{mmol}^{-2} \mathrm{~s}^{-1}\right)$. Average leaf temperature ranged between $34.00^{\circ} \mathrm{C}$ and $35.41^{\circ} \mathrm{C}$ with a mean of $34.92^{\circ} \mathrm{C}$. Average storage root yield varied from $15.58 \mathrm{t} \mathrm{ha}^{-1}$ to $34.45 \mathrm{tha}^{-1}$ for CTSIA 65 and UCC2001/449, respectively, with a mean of $25.56 \mathrm{tha}^{-1}$. Genotype 96/409 had the highest number of roots per plant (9.09) with PONTISANGE having the lowest number of roots per plant (5.95). Genotype MM96/1751 produced roots with the biggest girth $(7.21 \mathrm{~cm})$ whist the roots with the narrowest average girth were produced by CTSIA $45(4.33 \mathrm{~cm})$. The longest roots were produced by genotype $97 / 1708(48.19 \mathrm{~cm})$ whilst genotype CTSIA 65 produced the roots with the shortest length $(32.78 \mathrm{~cm})$. Harvest index ranged between 0.49 and 0.67 for CTSIA 65 and MM96/1751, respectively. Storage root length:girth ratio ranged between 5.08 and 11.68 with a mean of 7.68 .

\subsection{Principal Component Analysis under Different} Environments. Principal component analysis (PCA) explaining the relative contribution of the various traits to the performance of genotypes is presented in Table 9. At Fumesua (forest ecology), the first five principal component (PC) axes with eigenvalues of 0.97 to 3.56 cumulatively accounted for $78.39 \%$ of the total variation. PC1 which explained $27.4 \%$ of the variation had above ground biomass yield, cassava mosaic disease score, harvest index, storage root length, storage root number per plant, and storage root yield as the important traits. PC2 on the other hand explained $17.17 \%$ of the total variation and had number of branches per plant, number of leaves per plant, and stomatal conductance as the important traits. The third PC axis (PC3) had storage root length: girth ratio, leaf temperature, and root girth as the important traits and accounted for $15.6 \%$ of the variation. PC4 and PC5 accounted for $10.77 \%$ and $7.45 \%$, respectively. PC4 had only plant height as the trait driving the variability among the genotypes.

In the irrigated environment (Nyankpala irrigated), the first five PC axes with eigenvalues of 0.97 to 2.90 accounted 


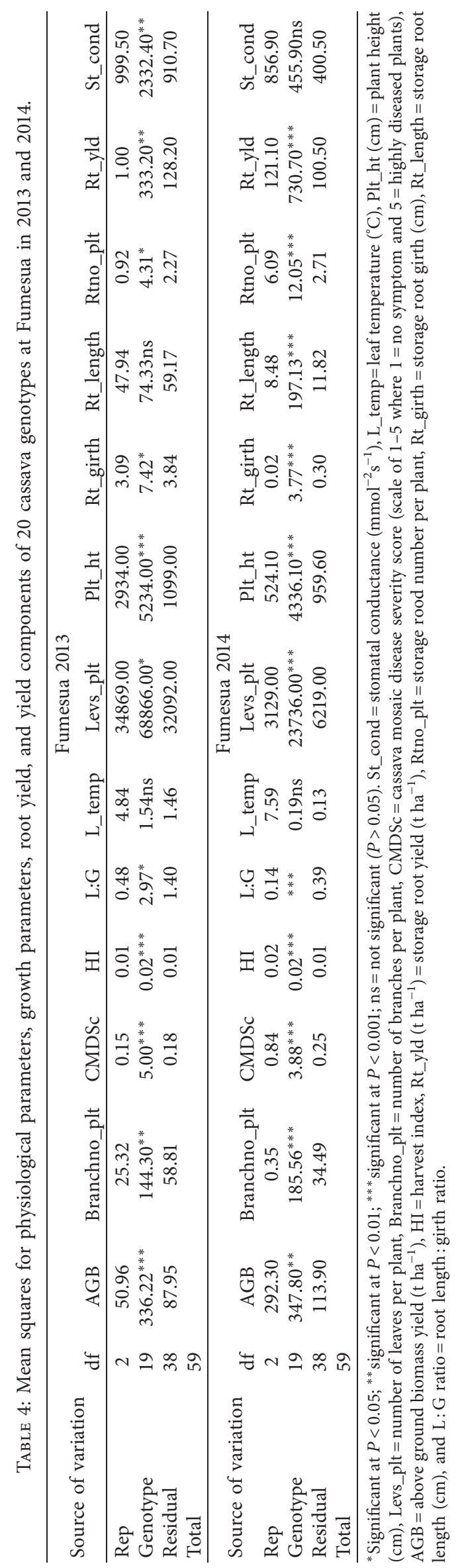




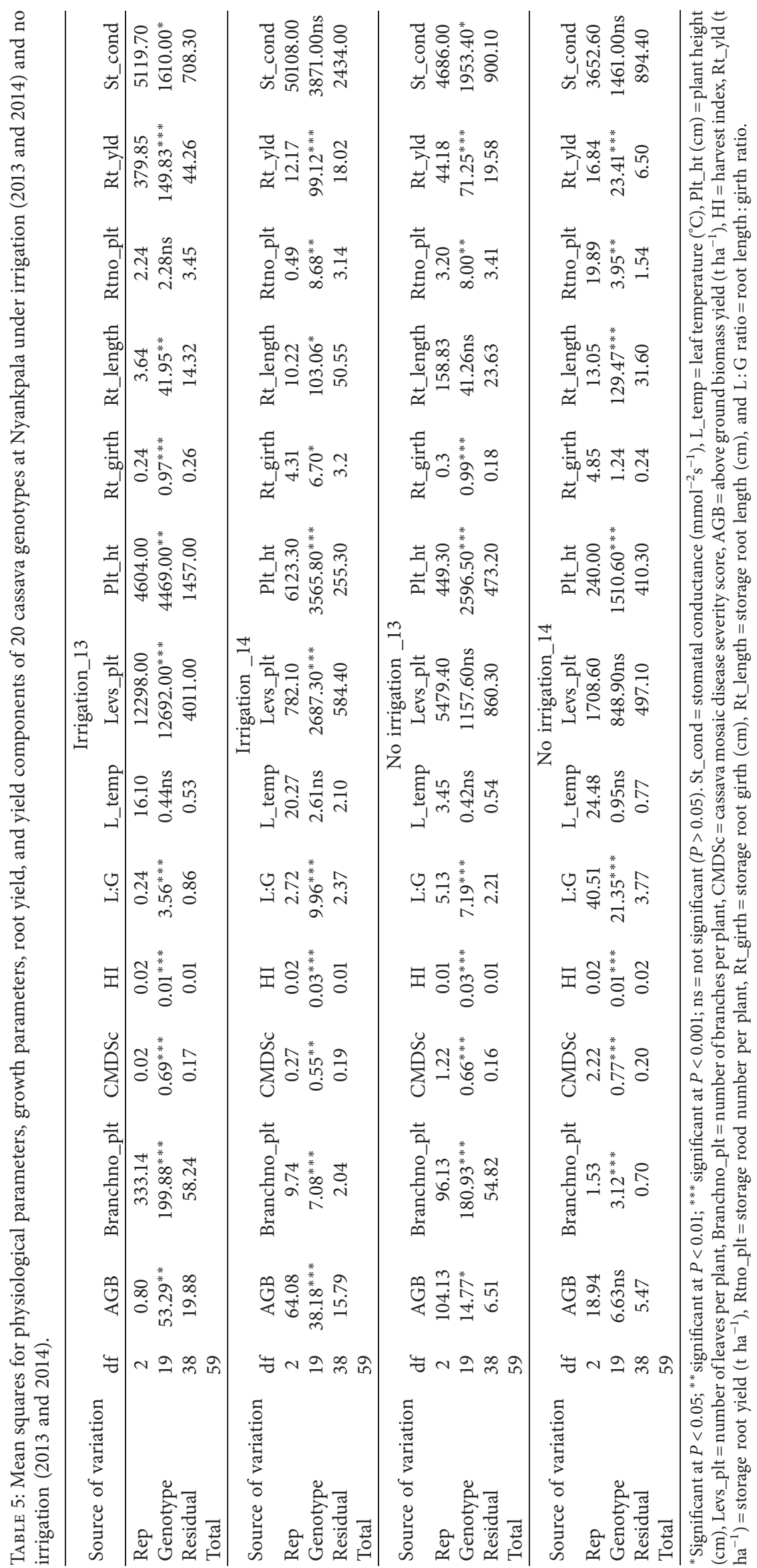


TABLE 6: Combined analysis of variance for physiological parameters, growth parameters, root yield, and yield components of 20 cassava genotypes in six environments.

\begin{tabular}{|c|c|c|c|c|c|}
\hline \multirow{2}{*}{ Traits } & \multicolumn{5}{|c|}{ Sources of variation (degrees of freedom) } \\
\hline & Environment $(\mathrm{E})(\mathrm{d} f=5)^{¥}$ & $\operatorname{Rep}($ Env $)(\mathrm{d} f=12)$ & Genotype $(\mathrm{G})(\mathrm{d} f=19)$ & $\mathrm{G} \times \mathrm{E}(\mathrm{d} f=95)$ & Error $(\mathrm{d} f=228)$ \\
\hline St_cond $\left(\mathrm{mmol}^{-2} \mathrm{~s}^{-1}\right)$ & $284443.82^{* * *}$ & 10666.25 & $2334.88^{* * *}$ & $1725.02^{* *}$ & 1051.04 \\
\hline Leaf temp $\left({ }^{\circ} \mathrm{C}\right)$ & $93.84^{* * *}$ & 11.41 & $1.46 \mathrm{~ns}$ & $0.85 \mathrm{~ns}$ & 0.93 \\
\hline Plt_ht $(\mathrm{cm})$ & $209255.70^{* * *}$ & 2479.1 & $15303.00^{* * *}$ & $1281.90^{* * *}$ & 775.7 \\
\hline Levs_plt & $388753.78^{* * *}$ & 9711.18 & $44420.61^{* * *}$ & $13113.46^{* *}$ & 7377.27 \\
\hline Branchno_plt & $1984.39^{* * *}$ & 77.69 & $388.37^{* * *}$ & $66.50^{* * *}$ & 34.84 \\
\hline CMDSc $(1-5)$ & $14.55^{* * *}$ & 0.58 & $6.13^{* * *}$ & $1.08^{* * *}$ & 0.19 \\
\hline $\operatorname{AGB}\left(\mathrm{t} \mathrm{ha}^{-1}\right)$ & $2999.32^{* * *}$ & 87.96 & $270.17^{* * *}$ & $104.54^{* * *}$ & 41.18 \\
\hline Harvest index & $0.436^{* * *}$ & 0.014 & $0.06^{* * *}$ & $0.02^{* * *}$ & 0.003 \\
\hline Rt_yld $\left(\mathrm{t} \mathrm{ha}^{-1}\right)$ & $3114.57^{* * *}$ & 95.86 & $715.89^{* * *}$ & $136.35^{* * *}$ & 52.18 \\
\hline Rtno_plt & $39.08^{* *}$ & 5.47 & $15.15^{* * *}$ & $4.83^{* * *}$ & 2.76 \\
\hline Rt_girth (cm) & $92.41^{* * *}$ & 2.09 & $12.11^{* * *}$ & $1.78^{*}$ & 1.314 \\
\hline Rt_length $(\mathrm{cm})$ & $2051.68^{* * *}$ & 40.16 & $348.85^{* * *}$ & $46.07^{*}$ & 31.61 \\
\hline $\mathrm{L}: \mathrm{G}$ ratio & $333.84^{* * *}$ & 8.19 & $34.96^{* * *}$ & $2.95^{* *}$ & 1.84 \\
\hline
\end{tabular}

${ }^{*}$ Significant at $P<0.05 ;{ }^{* *}$ significant at $P<0.01 ;{ }^{* * *}$ significant at $P<0.001$; ns $=$ not significant $(P>0.05) .{ }^{\mathrm{x}}$ Values in parenthesis represent the degrees of freedom for the various sources of variation. St_cond $=$ stomatal conductance $\left(\mathrm{mmol}^{-2} \mathrm{~s}^{-1}\right)$, Leaf temp $=$ leaf temperature $\left({ }^{\circ} \mathrm{C}\right)$, Plt_ht $(\mathrm{cm})=$ plant height $(\mathrm{cm})$, Levs_plt $=$ number of leaves per plant, Branchno_plt $=$ number of branches per plant, CMDSc $=$ cassava mosaic disease severity score $(\mathrm{scale}$ of $1-5$ where $1=$ no symptom and $5=$ highly diseased plants), $\mathrm{AGB}=$ above ground biomass yield $\left(\mathrm{t} \mathrm{ha}^{-1}\right), \mathrm{HI}=$ harvest index, Rt_yld $\left(\mathrm{t} \mathrm{ha}^{-1}\right)=$ storage root yield $\left(\mathrm{t} \mathrm{ha}{ }^{-1}\right)$, Rtno_plt = storage rood number per plant, Rt_girth = storage root girth $(\mathrm{cm})$, Rt_length = storage root length $(\mathrm{cm})$, and L: $\mathrm{G}$ ratio = storage root length : girth ratio.

TABLE 7: Estimates of variance components, heritability, and phenotypic and genotypic coefficients of variation for nine traits in 20 cassava genotypes across six environments.

\begin{tabular}{|c|c|c|c|c|c|c|c|c|c|c|}
\hline Traits & $\sigma_{g}^{2}$ & $\sigma_{g e}^{2}$ & $\sigma_{e}^{2}$ & $\sigma_{p}^{2}$ & $H^{2}$ & $G C V$ & $P C V$ & $P C V: G C V$ & $G A$ & $G A M$ \\
\hline St_cond $\left(\mathrm{mmol}^{-2} \mathrm{~s}^{-1}\right)$ & 186.61 & 127.67 & 1051.00 & 1365.28 & 13.67 & 7.58 & 20.49 & 2.70 & 19.23 & 10.67 \\
\hline Leaf temp $\left({ }^{\circ} \mathrm{C}\right)$ & 0.10 & 0.044 & 0.93 & 1.03 & 9.45 & 0.89 & 2.90 & 3.25 & 0.32 & 0.92 \\
\hline Plt_ht $(\mathrm{cm})$ & 878.29 & 84.37 & 775.70 & 1738.36 & 50.52 & 15.99 & 22.50 & 1.41 & 70.89 & 38.26 \\
\hline Levs_plt & 2786.50 & 956.00 & 7377.00 & 11119.50 & 25.06 & 38.79 & 77.48 & 2.00 & 65.80 & 48.34 \\
\hline Branchno_plt & 23.33 & 5.28 & 34.85 & 63.46 & 36.77 & 39.86 & 65.73 & 1.65 & 3.43 & 28.31 \\
\hline $\mathrm{CMDSc}^{-1}$ & 0.39 & 0.15 & 0.19 & 0.73 & 53.42 & 37.65 & 51.51 & 1.37 & 1.08 & 64.81 \\
\hline $\operatorname{AGBio}\left(\mathrm{t} \mathrm{ha}^{-1}\right)$ & 18.62 & 10.76 & 41.18 & 70.56 & 26.39 & 25.30 & 49.24 & 1.95 & 5.78 & 33.88 \\
\hline Rt_yld ( $\left.\mathrm{tha}^{-1}\right)$ & 44.85 & 14.14 & 52.18 & 111.17 & 40.34 & 26.20 & 41.25 & 1.57 & 10.34 & 40.46 \\
\hline Rt_girth (cm) & 0.70 & 0.08 & 1.32 & 2.09 & 33.39 & 14.56 & 25.19 & 1.73 & 1.25 & 21.83 \\
\hline Rt_length $(\mathrm{cm})$ & 20.54 & 2.49 & 31.61 & 54.64 & 37.59 & 11.17 & 18.21 & 1.63 & 3.35 & 8.26 \\
\hline Rtno_plt & 0.95 & 0.34 & 2.80 & 4.09 & 23.31 & 13.87 & 28.74 & 2.07 & 1.03 & 14.57 \\
\hline Harvest index & 0.0033 & 0.0004 & 0.0030 & 0.0067 & 49.04 & 9.9258 & 14.1736 & 1.4280 & 0.1140 & 19.7408 \\
\hline $\mathrm{L}: \mathrm{G}$ ratio & 2.02 & 0.19 & 1.73 & 3.94 & 51.27 & 18.49 & 25.83 & 1.40 & 1.44 & 18.70 \\
\hline
\end{tabular}

$\sigma_{g}^{2}=$ genotypic variance, $\sigma_{g e}^{2}=$ genotype $x$ environment variance, $\sigma_{e}^{2}=$ environmental variance, $\sigma_{p}^{2}=$ phenotypic variance, $H^{2}=$ broad-sense heritability, $P C V=$ phenotypic coefficient of variation, $G C V=$ genotypic coefficient of variation, $P C V: G C V=$ ratio of phenotypic to genotypic coefficients of variation, $G A=$ genetic advance, $G A M=$ genetic advance as percentage of the mean, St_cond = stomatal conductance $\left(\mathrm{mmol}^{-2} \mathrm{~s}^{-1}\right)$, Leaf temp $=$ leaf temperature $\left({ }^{\circ} \mathrm{C}\right)$, Branchno_plt $=$ number of branches per plant, Levs_plt $=$ number of leaves per plant, Plt_ht $(\mathrm{cm})=$ plant height $(\mathrm{cm})$, CMDSc $=$ cassava mosaic disease severity score (scale of $1-5$ where $1=$ no symptom and $5=$ highly diseased plants), AGBio $=$ above ground biomass yield $\left(\mathrm{t}\right.$ ha ${ }^{-1}$ ), $\mathrm{HI}=\mathrm{harvest} \mathrm{index}$, Rt_yld = storage root yield $\left(\mathrm{t} \mathrm{ha}^{-1}\right)$, Rtno_plt $=$ root number per plant, Rt_girth = storage root girth $(\mathrm{cm})$, Rt_length = storage root length $(\mathrm{cm})$, and L $: \mathrm{G}$ ratio $=$ root length : girth ratio.

for $71.85 \%$ of the total variation. PC1 (number of branches per plant, harvest index, storage root length: girth ratio, plant height, and storage root yield) accounted for $22.34 \%$ of the variation. Above ground biomass yield, number of leaves per plant, and number of roots per plant were the important traits under PC2 which explained $16.39 \%$ of the variation. The third PC (PC3) also explained $15.23 \%$ of the variation and had storage root girth and storage root length as the important traits. PC4 also explained $10.46 \%$ of the variation and had traits such as number of branches per plant, storage root length: girth ratio, etc., which had already been explained by the first three PC axes. PC5, however, had leaf temperature and stomatal conductance as the important traits and explained $7.43 \%$ of the total variation.

At Nyankpala (nonirrigated environment), the first five PC axes with eigenvalues of 1.11 to 3.19 explained $78.49 \%$ of the total variation with PC1 to PC5 accounting for $24.55,20.12,15.42,9.90$, and $8.5 \%$, respectively. However, the contribution of all the 13 traits to the total variation was explained by the first four PC axes. The important traits under $\mathrm{PC} 1$ were number of branches per plant, storage root length: girth ratio, leaf temperature, 


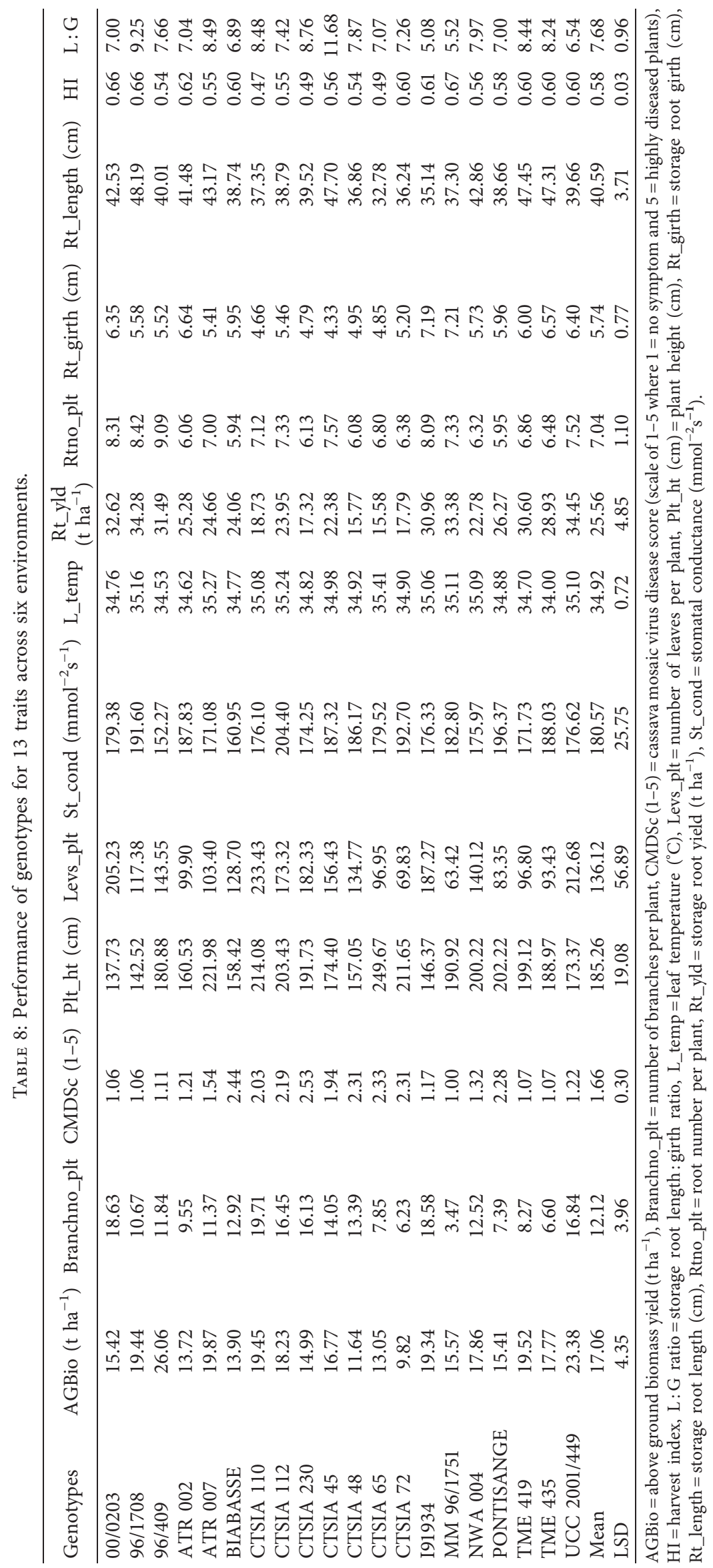




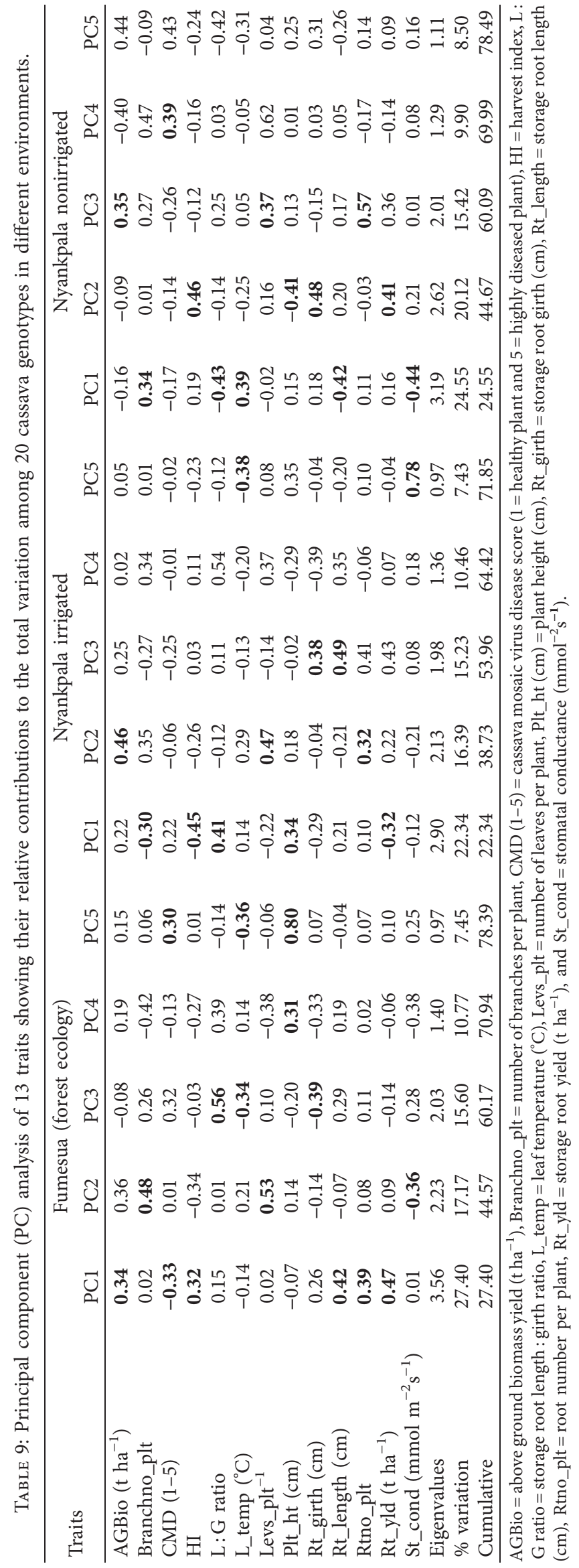


storage root length, and stomatal conductance. PC2 also had harvest index, plant height, storage root girth, and storage root yield as the important traits. PC3 had above ground biomass yield, number of leaves per plant, and number of roots per plant as the important traits whilst PC4 had cassava mosaic disease score as the remaining trait that had not been accounted for by the first three PC axes.

\subsection{Biplot Analysis for Performance and Stability}

3.8.1. Interrelationships among Traits and the Genotype and Environment Trait Profiles. The interrelationships among all the traits measured are presented in Figure 1. The first two principal components (PC1 and PC2) explained $55.4 \%$ of the total variation observed among the genotypes based on all the traits. The angle between traits indicates their association. Acute angle represents closely associated traits whilst wider angles or angles more than $90^{\circ}$ signify negatively correlated traits. Storage root yield, above ground biomass yield, and storage root girth were positively and closely associated and were the predominant traits that discriminated among genotypes. But the strongest association was between number of branches and number of leaves per plant and between root girth and harvest index. On the other hand, CMD which had a high discriminating power among genotypes was negatively associated with storage root yield, root length, root girth, and AGB. On the other hand, CMD which had a high discriminating power among genotypes was negatively associated with storage root yield, root length, root girth, and AGB. However, leaf temperature and storage root length: girth $(\mathrm{L}: \mathrm{G})$ ratio which were located at the biplot origin had low discriminatory power among genotypes and had negative association with storage root yield, harvest index, and storage root girth.

3.8.2. Genotype $\times^{\circ}$ Trait Analysis. Root girth, root yield, root length, and above ground biomass yield fell into different sectors (Figure 2). Genotypes MM96/1751, ATR 002, and TME 435 were closely associated with root girth and harvest index, whereas UCC2001/449 and 96/409 also had close association with above ground biomass yield and storage root number per plant. Genotype CTSIA 110 had the highest leaf temperature, $\mathrm{L}: \mathrm{G}$ ratio, number of branches, and number of leaves per plant. PONTISANGE was the genotype with the highest stomatal conductance. Genotypes CTSIA 65, CTSIA 48, and CTSIA 230 were closely associated with high cassava mosaic disease score. Genotypes I91934, UCC2001/449, 96/409, and 00/0203 also had close association with high storage root yield.

3.8.3. The Discriminativeness and Representativeness of Traits in Different Environments. The six environments were significantly different in terms of their influence on different physiological and yield traits of the genotypes (Figure 3).

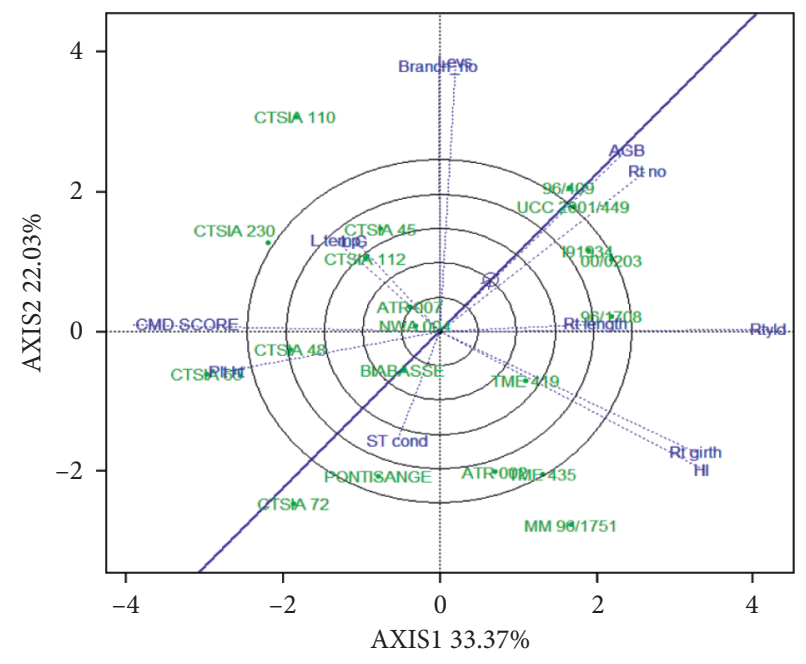

FIgURE 1: Vector view of the genotype $\times$ trait biplot on physiological traits of 20 genotypes of cassava showing the interrelationships among all traits in six environments. $A G B=$ above ground biomass yield $\left(\mathrm{t} \mathrm{ha}^{-1}\right)$, Branchno_plt $=$ number of branches per plant, CMD $(1-5)=$ cassava mosaic virus disease score ( $1=$ healthy plant and $5=$ highly diseased plant $), \mathrm{HI}^{\circ}={ }^{\circ}$ harvest index, $L: G$ ratio = storage root length : girth ratio, Leaf temp = leaf temperature $\left({ }^{\circ} \mathrm{C}\right)$, Levs_plt $=$ number of leaves per plant, Plt_ht $(\mathrm{cm})=$ plant height $(\mathrm{cm})$, Rt_girth = storage root girth $(\mathrm{cm})$, Rt_length $=$ storage root length $(\mathrm{cm})$, Rtno_plt $=$ root number per plant, Rt_yld = storage root yield $\left(\mathrm{t} \mathrm{ha}^{-1}\right)$, and St_cond = stomatal conductance $\left(\mathrm{mmol}^{-2} \mathrm{~s}^{-1}\right)$.

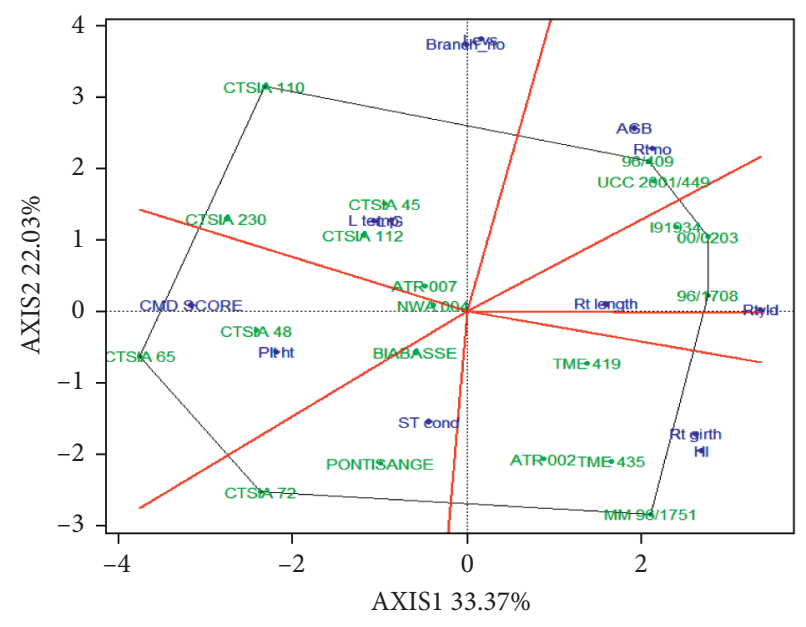

FIgURE 2: The "which won where" view of the genotype $\times$ trait biplot analysis of physiological traits of 20 genotypes of cassava among all traits in six environments. $\mathrm{AGB}=$ above ground biomass yield $\left(\mathrm{t} \mathrm{ha}^{-1}\right)$, Branchno_plt $=$ number of branches per plant, CMD $(1-5)=$ cassava mosaic virus disease score $(1=$ healthy plant and $5=$ highly diseased plant), $\mathrm{HI}^{\circ}={ }^{\circ}$ harvest index, $\mathrm{L}: \mathrm{G}$ ratio $=$ storage root length: girth ratio, Leaf temp = leaf temperature $\left({ }^{\circ} \mathrm{C}\right)$, Levs_plt $=$ number of leaves per plant, Plt_ht $(\mathrm{cm})=$ plant height $(\mathrm{cm})$, Rt_girth = storage root girth $(\mathrm{cm})$, Rt_length = storage root length $(\mathrm{cm})$, Rtno_plt = root number per plant, Rt_yld = storage root yield $\left(\mathrm{t} \mathrm{ha}^{-1}\right)$, and St_cond $=$ stomatal conductance $\left(\mathrm{mmol}^{-2} \mathrm{~s}^{-1}\right)$. 


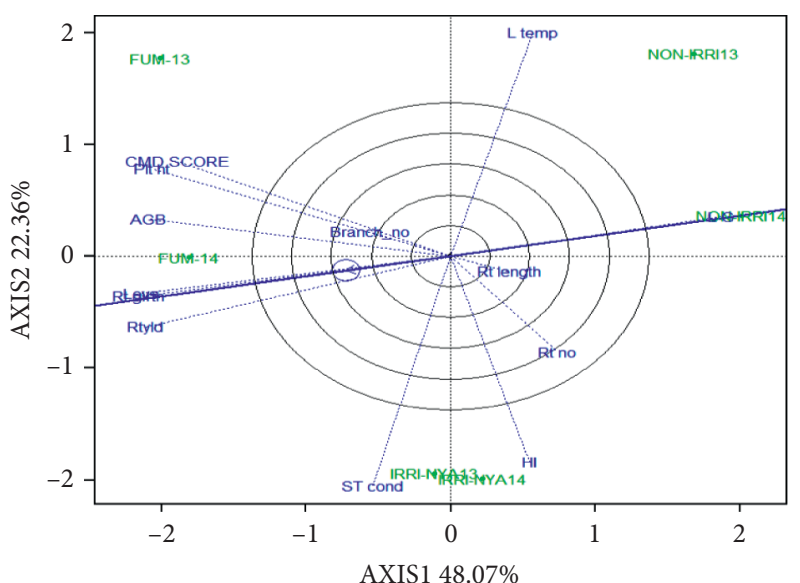

FIgURE 3: Relationships between traits and different environments. FUM-13 = Fumesua 2013, NON-IRRI13 = no irrigation 2013, IRRINYA13 = irrigation 2013, FUM-14 = Fumesua 2014, NONIRRI14= no irrigation 2014, and IRRI-NYA14=irrigation 2014. $\mathrm{AGB}=$ above ground biomass yield $\left(\mathrm{t} \mathrm{ha}^{-1}\right)$, Branchno_plt $=$ number of branches per plant, CMD $(1-5)=$ cassava mosaic virus disease score $(1=$ healthy plant and $5=$ highly diseased plant), $\mathrm{HI}^{\circ}={ }^{\circ}$ harvest index, $\mathrm{L}: \mathrm{G}$ ratio $=$ storage root length $:$ girth ratio, Leaf temp $=$ leaf temperature $\left({ }^{\circ} \mathrm{C}\right)$, Levs_plt ${ }^{-1}=$ number of leaves per plant, Plt_ht $(\mathrm{cm})=$ plant height $(\mathrm{cm})$, Plant_yld = storage root yield $\left(\mathrm{t} \mathrm{ha}^{-1}\right)$, and St_cond = stomatal conductance $\left(\mathrm{mmol}^{-2} \mathrm{~s}^{-1}\right)$.

Cassava mosaic disease, number of leaves per plant, storage root girth, and storage root yield were the most discriminating traits in Fumesua 2013 and 2014. Under irrigation in 2013 and 2014, stomatal conductance and harvest index were the most discriminating traits, whilst high leaf temperature was mostly associated with the nonirrigated environments in 2013 and 2014. Storage root length, though having a low discriminating power, was associated with the nonirrigated environments.

3.8.4. Relationships between Test Environments. The length of the vertex of an environment indicates the discriminatory power of that particular environment (Figure 4). This identified Fumesua 2014 as the most discriminatory environment followed by Fumesua 2013. These were followed by the two irrigated environments (IRRI-NYA13 and IRRINYA14) and the nonirrigated environments (NON-IRRI13 and NON-IRRI14). The angle between environments indicates their association. Acute angle represents close association whilst very wide angle indicates weak association. There were little variations between the two irrigated environment and also the two nonirrigated environments. The most diverse environments were Fumesua 2013 and Fumesua 2014.

3.8.5. GGE Biplot Analysis for Storage Root Yield. The biplot showed that the first two principal component axes accounted for $88.64 \%$ of the variation due to $G^{\circ} \times{ }^{\circ} E$ on root yield (Figure 5). Three genotypes, 00/0203, MM96/1751, and

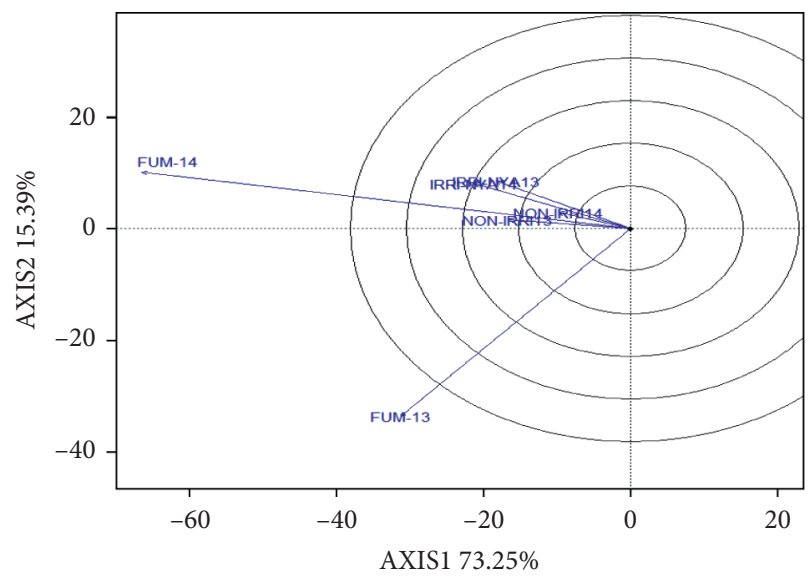

FIgURE 4: Relationship between environments. FUM$13=$ Fumesua 2013, NON-IRRI13 = no irrigation 2013, IRRINYA13 = irrigation $2013, \quad F U M-14=$ Fumesua $2014, \quad$ NONIRRI14= no irrigation 2014, and IRRI-NYA14=irrigation 2014.

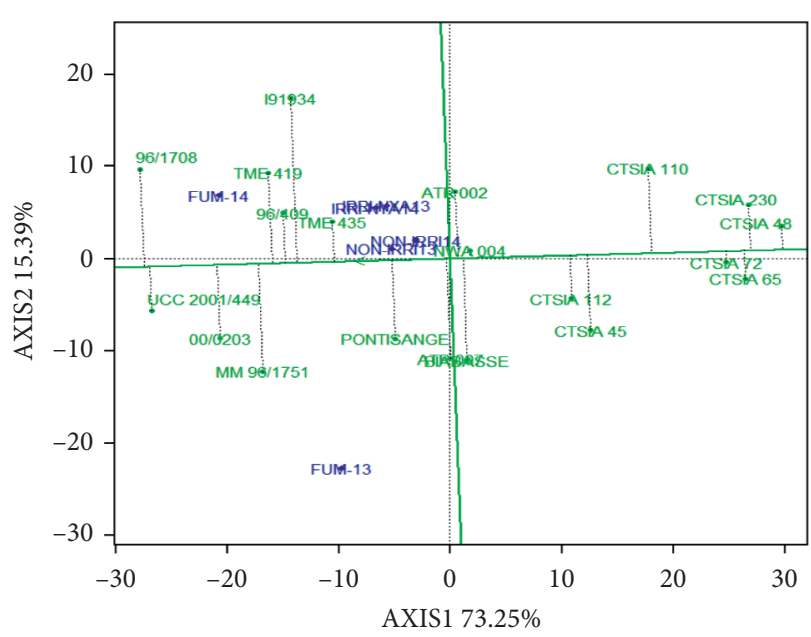

FIGURE 5: Comparison biplot for storage root yield of 20 cassava genotypes in six environments. FUM-13 = Fumesua 2013, NONIRRI13 = no irrigation 2013, IRRI-NYA13 = irrigation 2013, FUM$14=$ Fumesua 2014, NON-IRRI14 = no irrigation 2014, and IRRINYA14 = irrigation 2014.

UCC2001/449, were identified as both high yielding and stable based on their production to the horizontal line that divides the biplot into two. Genotypes 96/1708, I91934, TME 419 , and TME 435 were high yielding but unstable. The most stable genotype is CTSIA 112 which appeared close to the origin of the biplot. Genotypes CTSIA 65, CTSIA 48, CTSIA 72, CTSIA 110, and CTSIA 230 were low yielding given their performance was below the overall average.

3.8.6. GGE Biplot for Genotypes with the Highest Root Yield in Different Environments. The convex-hull drawn on genotypes from the biplot origin identified eight sectors with UCC2001/449, MM96/1751, 96/1708, I91934, CTSIA 110, CTSIA 65, and Biabasse as the vertex genotypes (Figure 6). 


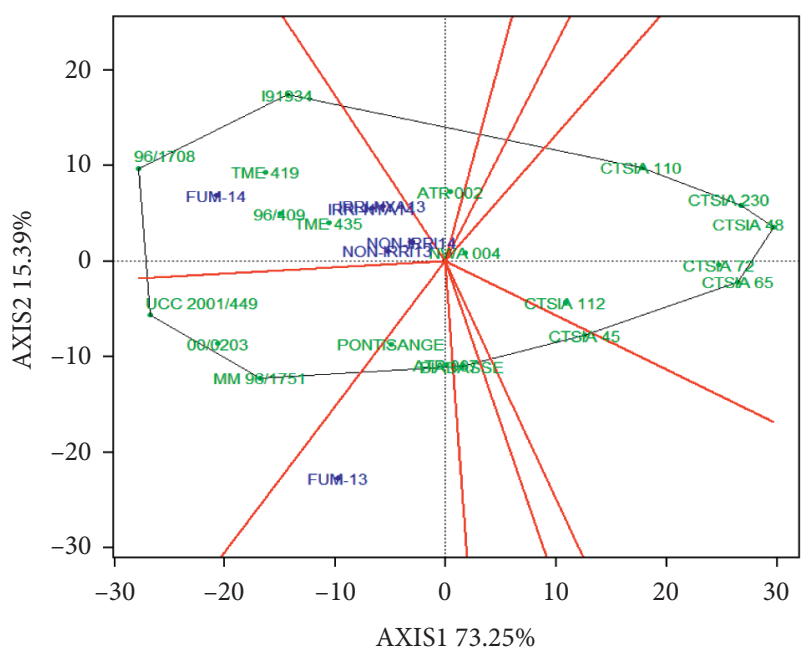

FIGURE 6: GGE biplot showing best genotypes for fresh root yield (t/ha) of 20 cassava genotypes in six environments. FUM$13=$ Fumesua 2013, NON-IRRI13= no irrigation 2013, IRRINYA13 = irrigation 2013, FUM-14 = Fumesua 2014, NONIRRI14 = no irrigation 2014, and IRRI-NYA14 = irrigation 2014.

Environments irrigation 2014, no irrigation 2014, and no irrigation 2013 all fell within the sector with 96/1708 as the wining genotype. No environment fell in the sector with CTSIA 65, CTSIA 110, and Biabasse, indicating that these genotypes were unresponsive and were the poorest genotypes in some or all of the environments. The biplot also suggested the existence of megaenvironments among the sites used. The groupings indicated that environments FUM13 and FUM-14 fell within the sector with genotype UCC2001/449 and 00/0203 as the wining genotypes. However, environment IRR13 was identified as distinct from the others and fell within the sector with genotype I91934 as the wining genotype.

\section{Discussion}

Cassava responds to varying environmental conditions through a series of physiological processes [3, 45-47] which include stomatal closure that decreases stomatal conductance and increase in leaf temperature. Under optimum conditions, cassava plants generally maintain high stomatal conductance for optimum growth and in some cases translate into high root yield $[3,48]$. These secondary traits are often used for indirect selection for yield [11]. Apart from leaf temperature, all the other traits were significantly influenced by GEI effect. Though significant genotypic variation was observed for stomatal conductance, it was strongly influenced by the environment as well as GEI which resulted in its low broad-sense heritability. GEI arises as a result of differences in the sensitivities of different genotypes [49] and leads to variations in the ranking of genotypic performance in different environments $[50,51]$. This often confounds effective selection based on such traits across different environments in plant breeding programmes [52]. For traits that are subject to environmental influences, several environments are required for evaluation in order to eliminate the effect of $G^{\circ} \times{ }^{\circ} E$ to make them useful as selection indices [53]. Multienvironment evaluations allow the target environments to be tested for homogeneity and be partitioned into various megaenvironments for effective selection [52]. Traits that are not easily influenced by the environment and GEI could be more useful as selection indices in different environments since ranking of genotypes based on such traits will not differ significantly in different environments [20].

Different genotypes differed in their physiological responses to different growing conditions (soil, moisture, temperature, and relative humidity) under different environments. For instance, leaf temperature was higher across genotypes under the dry conditions (nonirrigated compared with the forest and irrigated environment). Increase in leaf temperature results from the partial stomatal closure under moisture stress, thereby preventing the dissipation of heat from metabolic processes [54]. This was evident in the negative correlation between leaf temperature with stomatal conductance and leaf temperature with storage root yield and varied among the genotypes and the environments. This confirms earlier report that leaf temperature drops below air temperature when water evaporates from leaves, thus making temperature an indirect measure of the instantaneous transpiration at the whole-crop level [55] and plant water status [16]. This suggests that genotypes which undergo active transpiration under moisture stress maintain low leaf temperature, indicating their tolerance to these stress conditions. The observed genotypic variability for leaf temperature provides opportunity to exploit its measurement for assessing transpiration rate and activities of cassava plants under moisture stress. This can then be used to screen for tolerant genotypes under stress as have been done for crops like potato [36] and wheat $[16,56]$.

Growth parameters such as number of leaves, number of branches, and above ground biomass were significantly influenced by the genotypes and the growing environment as have been reported in earlier studies $[22,46]$. Though leaf abscission is a key mechanism employed by plants to minimise water loss under limited moisture conditions $[3,57]$, excessive leaf abscission often leads to reduction in photosynthesis and hence dry matter production [18]. Moisture stress conditions accelerate leaf senescence, reduce canopy size, and reduce rate of photosynthesis and yield [58]. This often results from the production of abscisic acid by root tips which stimulate the leaf abscission process $[9,59,60]$. Cassava genotypes with greater leaf production ability and retention have been reported to produce much higher total fresh biomass and up to $33 \%$ higher root dry matter compared to drought-susceptible genotypes [18].

Most quantitative traits are strongly influenced by genotype $\times$ environment interaction which confounds effective selection, particularly different genotypes for specific environments. Stability analysis has often been limited to yield across several environments without considering the other secondary traits $[24,25]$. Other forms of stability analysis such as genotype ${ }^{\circ} \times{ }^{\circ}$ trait analysis and environment ${ }^{\circ} \times{ }^{\circ}$ trait analysis have been used to perform multivariate 
analysis and association between different traits in different environments. This has enabled the identification of traits that need to be targeted in these environments for utilization as secondary traits in indirect selection [24, 61]. The genotype $x^{\circ}$ trait biplot analysis revealed association between certain traits and the best genotypes closely associated with these traits based on their mean performance across environments. For instance, close associations were observed between the root yield and yield components (root yield, root girth, stomatal conductance, and above ground biomass yield) and were mostly associated with genotypes TME 435, TME 419, and UCC2001/449. The interrelationships among these traits and associations with different environments could be attributed to differential partitioning of dry matter into the above ground parts and storage roots $[1,45]$. In some cases, cassava plants extend their roots into deeper soil layers for moisture absorption $[47,62]$ aided by accumulation of dry matter for root extension rather than expansion in girth [47]. This possibly accounted for the higher storage root length : girth ratio in the stress environments compared with the favourable environments (under irrigation and in humid ecology) as well as the strong influence of $G \times E$ interaction [8]. This implies that genotypes tend to extend their roots to deeper soil layers for moisture uptake in stress environments [57] instead of expansion in root girth. Extension of cassava roots into deeper soil layers occurs at the initial stages of growth before starch deposition in storage roots commences [45]. It has been assumed that cassava genotypes develop equal root lengths but the final root yield depends on the source-sink relationship and the amount of dry matter that is partitioned for root expansion $[1,45]$.

Cassava mosaic disease severity score was closely associated with the genotypes CTSIA 110, CTSIA 112, CTSIA 230, CTSIA 45, CTSIA 48, CTSIA 65, and CTSIA 72. This visual revelation of genotypes and associated traits has been proposed in earlier studies through genotype ${ }^{\circ} \times{ }^{\circ}$ trait biplot analysis, as an efficient way of visualizing genetic correlation among trait studies [25-27, 61, 63]. It also enables the evaluation of genotypes based on multiple traits and provides information on useful and less important traits that can be used in indirect selection in multivariate analysis $[26,63]$. Environment ${ }^{\circ} \times{ }^{\circ}$ trait biplot also enables the visualization of the relationships between traits in different environments and what traits drive the variability among different genotypes evaluated in these environments [24]. This revealed that storage root length and storage root length: girth (L:G) ratio were mostly associated with the moisture stress environments, and as such they can be used as surrogate traits for selecting genotypes adapted to stress ecologies. On the other hand, root yield, storage root girth, number of leaves per plant, and above ground biomass yield were closely associated with the forest ecology and under irrigated conditions. Similar patterns of these traits and their associated environments were revealed by the principal component analyses of different responsive traits under different growing environments. This suggests that both the genotype ${ }^{\circ} \times{ }^{\circ}$ trait and environment $x^{\circ}$ trait biplot analyses are reliable tools for visualizing and identifying correlation between traits and associated genotypes in different environments, unlike other correlation analyses that only indicate association between traits and not the associated genotypes.

Furthermore, GEI analysis for fresh storage root yield and yield components indicated significance effect and were particularly high in the more favourable growing environments as have been observed in previous studies $[4,46]$. This necessitated the use of stability analysis methods to identify genotypes that have predictable performance and respond positively to improvements in environmental conditions [64]. In the presence of significant GEI, genotypes need to be evaluated in several environments to identify those that remain consistent or stable $[20,21]$. However, stability per se does not warrant selection for a performance since a consistently poor genotype can still be considered stable [24]. Therefore, multienvironment trials are conducted to select favorable genotypes based on mean performance and stability of the trait in question [20,65].

The observed phenotypic variance for number of leaves per plant was mostly due to genetic influence and suggests the presence of an inherent genetic potential for the improvement of this trait [66]. This observation was contrary to an earlier study in aerial yam that revealed lower genetic variances for leaf production, an indication of stronger environmental influence [67]. Though large genetic variances $\left(\sigma_{g}^{2}\right)$ were observed for a number of traits, their error variances were still higher than their respective genotypic and $G^{\circ} \times^{\circ} E$ variances $\left(\sigma_{g e}^{2}\right)$ in most cases, implying strong environmental influence. This was again evidence in the greater magnitude of the differences between the phenotypic and genotypic coefficients of variation. Earlier studies have reported that greater magnitude of differences between genotypic and phenotypic coefficients of variation is evidence of stronger environmental influence and as such will be difficult to use such traits in indirect selection [2, 68]. Root yield components such as root girth, root length, and root length: girth ratio were influenced by their genetic variances more than the interaction variances, indicating that genetic improvement can be made with selection [23]. Broad-sense heritability estimates recorded for number of roots per plant and plant height were similar to the findings of an earlier study which reported 39.9, 53.8, and $41.9 \%$, respectively, for these traits [23]. Heritability estimates indicate the amount of progress that can be made in future performance for a trait [69] and suggests that traits with high broad-sense heritability could be targeted for selection. However, other studies have reported that broad-sense heritability does not fully reflect the amount of progress that can be from selection; it is used in combination with genetic advance [7]. Genetic advance for most of the traits were low indicating that slow progress would be made when selecting for those traits in this population. The analysis further indicated that estimates of genetic advance as a percentage of the mean performance was high for CMD score and moderate for storage root yield, number of leaves per plant, and plant height, whilst the lowest improvement is expected in reduction in leaf temperature. Traits with low genetic advance and genetic advance as percentage of mean are difficult to improve with simple selection [7, 23, 69]. 


\section{Conclusions}

Genotype and genotype $\times$ environment interaction effects were significant for most of the important traits studied. The GGE biplot provided visual illustration of relationships between different physiological traits among the cassava genotypes in different environments. The different traits exhibited different discriminatory properties among genotypes in the different environments and their relationships with storage root yield. The principal component analyses identified number of branches per plant, storage root length : girth ratio, storage root length, and stomatal conductance as the most important traits driving the genetic variability among genotypes in the moisture stress environments (no irrigation 2013 and 2014). Above ground biomass yield, cassava mosaic disease score, storage root length, and storage root yield were the most important traits accounting for greater genetic variability in the forest environment (Fumesua 2013 and 2014). Leaf temperature, stomatal conductance, number of storage roots per plant, number of leaves per plant, and above ground biomass had low broadsense heritability estimates making them unsuitable as secondary traits for selection. Moderate broad-sense heritability estimates were found for storage root yield, harvest index, plant height, storage root length:girth ratio, and cassava mosaic disease score. This study has identified important physiological traits of significant genetic basis that can be targeted in different environments for yield improvement in cassava.

\section{Data Availability}

The data used to support the findings of the study are included within the article.

\section{Conflicts of Interest}

The authors declare that they have no conflicts of interest regarding the publication of this paper.

\section{Acknowledgments}

The authors acknowledge the support of the management and staff of the CSIR-Savanna Agricultural Research Institute, Nyankpala, and the CSIR-Crops Research Institute, Fumesua, Kumasi. The authors are also grateful to the Generation Challenge Programme and the Alliance for Green Revolution in Africa for their support.

\section{Supplementary Materials}

Genotypic performances for different traits varied in various environments resulting in crossover interactions (Supplementary Tables 1-13). For above ground biomass (AGB) yield (Supplementary Table 1), the highest average yield of all genotypes was recorded at Fumesua in 2013 with the least coming from Nyankpala under no irrigation in 2013 (NONIRRI-2013). The highest overall AGB yield (48.91 $\mathrm{t} \mathrm{ha}^{-1}$ ) was given by genotype $96 / 1708$ at Fumesua in 2014. The least $\left(5.75 \mathrm{tha}^{-1}\right)$ was recorded Nyankpala under no irrigation in
2013 (NON-IRRI-13) from 00/0203. Genotype $\times$ environment interaction effect on number of branches per plant was evident as performances of genotypes differed in different environments (Supplementary Table 2). The highest mean number of branches per plant (18.63) was recorded at Nyankpala under no irrigation in 2013 (NON-IRRI-13) with the least ( 5 branches per plant) also being recorded at Nyankpala under no irrigation in 2014 (NON-IRRI-14). Crossover interaction was also observed for reaction genotypes to cassava mosaic disease (CMD) score (Supplementary Table 3). The highest CMD score (4.7) was recorded at Fumesua on genotype CTSIA 230. Most of the genotypes had high CMD scores at Fumesua in both years which had environmental averages of 2.24 and 2.35, respectively, for Fumesua in both 2013 and 2014. Though there were changes in the ranking of genotypes, some of the genotypes (CTSIA 65, CTSIA 230, PONTISANGE, and BIABASSE) had high CMD scores across all the environments. Genotypes varied in plant height in different environments (Supplementary Table 4). The highest mean plant height was recorded at Fumesua in 2013 (FUM-13; $266.15 \mathrm{~cm}$ ) with the lowest being recorded at Nyankpala in 2014 under no irrigation (NONIRRI-14; $125.86 \mathrm{~cm})$. The tallest height recorded was $338.30 \mathrm{~cm}$ for NWA 004 at Fumesua in 2013 with the shortest coming from 96.1708 (88.50 recorded at Nyankpala under no irrigation in 2014 (NON-IRRI-14)). Number of leaves per plant also significantly varied among genotypes in different environments (Supplementary Table 5). The highest mean number of leaves was 227.51 at Fumesua in 2013 with the least (40.83) being recorded at Nyankpala under no irrigation (NON-IRRI-14). Genotype 00/0203 produced the highest number of leaves at Fumesua in 2013 but other genotypes produced the highest number of leaves in other environments. The highest mean stomatal conductance $\left(255.86 \mathrm{mmol}^{-2} \mathrm{~s}^{-1}\right)$ was recorded under irrigation in 2013 with the least $\left(68.17 \mathrm{mmol}^{-2} \mathrm{~s}^{-1}\right)$ being recorded under no irrigation in 2013 (Supplementary Table 6). Apart from NON-IRRI-14, genotypic variation was significant in all the other environments as well as reranking of the genotypic performance from one environment to the other. Though the environment had significant effect on the leaf temperature, genotype effects and genotype $\times$ environment interaction effects were not significant (Supplementary Table 7). The highest mean leaf temperature $\left(36.98^{\circ} \mathrm{C}\right)$ was recorded at NON-IRRI-13 with the lowest mean leaf temperature $\left(33.67^{\circ} \mathrm{C}\right)$ being recorded at IRRI-NYA-14. The ranking of genotypes varied from one environment to the other for storage root yield (Supplementary Table 8). The highest mean storage root yield for all genotypes (34.83 $\mathrm{tha}^{-1}$ ) was obtained at FUM-13 with the lowest (16.34 $\mathrm{tha}^{-1}$ ) being recorded at NON-IRRI-14. Genotype 96/ 1708 had the highest recorded storage root yield (61.61 tha $\mathrm{th}^{-1}$ at FUM-14) among genotypes in all environments with genotype CTSIA 65 giving the least storage root yield (7.79 $\mathrm{tha}^{-1}$ at NON-IRRI-14) recorded in all the environments. Ranking of genotypes for storage root number per plant varied in different environments (Supplementary Table 9). The highest mean number of roots per plant (8) was recorded at IRRI-NYA-14. Genotype 96/409 produced the 
most roots in three out of the six environments. Mean storage root girth was highest $(7.01 \mathrm{~cm})$ at FUM-14 with the smallest mean root girth $(4.09 \mathrm{~cm})$ being recorded at NONIRRI-14 (Supplementary Table 10). Genotype ATR 002 produced the widest root girth $(11.17 \mathrm{~cm}$ at FUM-13) among all genotypes in different environments with the smallest $(2.96 \mathrm{~cm}$ in NON-IRRI-14) being recorded on CTSIA 45. The ranking of genotypes for storage root length changed in different environments (Supplementary Table 11). NONIRRI-14 had the longest mean root length $(48.00 \mathrm{~cm})$ recorded from all genotypes with IRRI-NYA-13 having the shortest mean root length $(33.94 \mathrm{~cm})$ recorded for all genotypes. The longest roots $(60.59 \mathrm{~cm})$ were recorded on genotype TME 419 at NON-IRRI-14 with the shortest roots $(25.17 \mathrm{~cm})$ being recorded on CTSIA 65 at FUM-13. Mean harvest index was highest at 0.71 at IRRI-NYA-13 with the lowest (0.47) being recorded at FUM-13 (Supplementary Table 12). The rankings also varied from one environment to the other. The highest mean storage root length: girth $(L: G)$ ratio (11.94) was recorded in NON-IRRI-14, with the least (5.36) being recorded in FUM-13 (Supplementary Table 13). Though the rankings changed from one environment to the other, the highest L: G ratio (18.61) was recorded on genotype CTSIA 45 at NON-IRRI-14 with genotype ATR 002 giving the least recorded L:G ratio (3.94) at FUM-13. Smaller mean L: G ratios were recorded at Fumesua in both 2013 and 2014 and under irrigation compared to the nonirrigated environments (NON-IRRI-13 and NON-IRRI-14). (Supplementary Materials)

\section{References}

[1] M. A. El-Sharkawy, "Cassava biology and physiology," Plant Molecular Biology, vol. 56, no. 4, pp. 481-501, 2004.

[2] O. O. Aina, A. G. O. Dixon, and E. A. Akinrinde, "Effect of soil moisture stress on growth and yield of cassava in Nigeria," Pakistan Journal of Biological Sciences, vol. 10, no. 18, pp. 3085-3090, 2007.

[3] M. A. El-Sharkawy, "Physiological characteristics of cassava tolerance to prolonged drought in the tropics: implications for breeding cultivars adapted to seasonally dry and semiarid environments," Brazilian Journal of Plant Physiology, vol. 19, no. 4, pp. 257-286, 2007.

[4] L. F. Turyagyenda, E. B. Kizito, Y. Baguma, and D. Osiru, "Evaluation of Ugandan cassava germplasm for drought tolerance," International Journal of Agriculture and Crop Sciences, vol. 5, no. 3, pp. 212-226, 2013.

[5] P. C. Haldavankar, G. D. Joshi, S. G. Bhave, R. G. Klandekar, and S. S. Sawant, "Stability of yield and yield attributing phenotypic characters in sweet potato," Journal of Root Crops, vol. 35, no. 1, pp. 28-35, 2009.

[6] L. F. Turyagyenda, E. B. Kizito, M. Ferguson et al., "Physiological and molecular characterization of drought responses and identification of candidate tolerance genes in cassava," AoB Plants, vol. 5, pp. 1-17, 2013.

[7] J. Adjebeng-Danquah, V. E. Gracen, S. K. Offei, I. K. Asante, and J. Manu-Aduening, "Agronomic performance and genotypic diversity for morphological traits among cassava genotypes in the Guinea Savannah Ecology of Ghana," Journal of Crop Science and Biotechnology, vol. 19, no. 1, pp. 99-108, 2016.
[8] J. Adjebeng-Danquah, V. E. Gracen, S. K. Offei, I. K. Asante, and J. Manu-Aduening, "Genetic variability in storage root bulking of cassava genotypes under irrigation and no irrigation," Agriculture \& Food Security, vol. 5, no. 9, pp. 1-12, 2016.

[9] A. A. C. Alves and T. L. Setter, "Abscisic acid accumulation and osmotic adjustment in cassava under water deficit," Environmental and Experimental Botany, vol. 51, no. 3, pp. 259-271, 2004.

[10] A. Efisue, P. Tongoona, J. Derera, B. E. Ubi, and H. O. Oselebe, "Genetics of morpho-physiological traits in segregating populations of interspecific hybrid rice under stress and nonstress conditions," Journal of Crop Improvement, vol. 23, no. 4, pp. 383-401, 2009.

[11] R. Karimizadeh, M. Mohammadi, and S. Ghaffaripour, "Evaluation of physiological screening techniques for drought-resistant breeding of durum wheat genotypes in Iran," African Journal of Biotechnology, vol. 10, no. 56, pp. 12107-12117, 2011.

[12] R. Karimizadeh and M. Mohammadi, “Association of canopy temperature depression with yield of durum wheat genotypes under supplementary irrigated and rainfed conditions," Australian Journal of Crop Science, vol. 5, no. 2, pp. 138-146, 2011.

[13] M. K. Osei, B. Annor, J. Adjebeng-Danquah et al., "Genotype $\mathrm{x}$ Environment Interaction: a prerequisite for tomato variety development," in Recent Advances in Tomato Breeding and Production, S. T. Nyaku and A. Danquah, Eds., IntechOpen, London, UK, pp. 71-91, 2018.

[14] C. N. Egesi, P. Ilona, F. O. Ogbe, M. Akoroda, and A. Dixon, "Genetic variation and genotype $\mathrm{x}$ environment interaction for yield and other agronomic traits in cassava in Nigeria," Agronomy Journal, vol. 99, no. 4, pp. 1137-1142, 2007.

[15] H. P. Piepho, "A mixed-model approach to mapping quantitative trait loci in barley on the basis of multiple environment data," Genetics, vol. 156, no. 4, pp. 2043-2050, 2000.

[16] J. L. Araus, G. A. Slafer, M. P. Reynolds, and C. Royo, "Plant breeding and drought in C3 cereals: what should we breed for?" Annals of Botany, vol. 89, no. 7, pp. 925-940, 2002.

[17] G. O. Edmeades, J. Bolanos, A. Elings, J.-M. Ribaut, M. Banziger, and M. E. Westgate, "The role and regulation of the anthesis-silking interval in maize," in Physiology and Modelling Kernel Set in Maize, M. E. Westgate and K. J. Boote, Eds., pp. 43-73, CSSA, Madison, WI, USA, 2000.

[18] J. I. Lenis, F. Calle, G. Jaramillo, J. C. Perez, H. Ceballos, and J. H. Cock, "Leaf retention and cassava productivity," Field Crops Research, vol. 95, no. 2-3, pp. 126-134, 2006.

[19] L. Cattivelli, F. Rizza, F. W. Badeck et al., "Drought tolerance improvement in crop plants: an integrated view from breeding to genomics," Field Crops Research, vol. 105, no. 2, pp. 1-14, 2008.

[20] J. Adjebeng-Danquah, J. Manu-Aduening, V. E. Gracen, I. K. Asante, and S. K. Offei, "AMMI stability analysis and estimation of genetic parameters for growth and yield components in cassava in the forest and Guinea savannah ecologies of Ghana," International Journal of Agronomy, vol. 2017, Article ID 8075846, 10 pages, 2017.

[21] G. Ssemakula and A. Dixon, "Genotype x environment interaction, stability and agronomic performance of carotenoidrich cassava clones," Scientific Research and Essay, vol. 2, pp. 390-399, 2007.

[22] O. O. Aina, A. G. O. Dixon, P. Illona, and E. A. Akinrinde, " $\mathrm{G} \times \mathrm{E}$ interaction effects on yield and yield components of cassava (landraces and improved) genotypes in the savanna 
regions of Nigeria," African Journal of Biotechnology, vol. 8, no. 19, pp. 4933-4945, 2009.

[23] P. Ntawuruhunga and A. Dixon, "Quantitative variation and interrelationship between factors influencing cassava yield," Journal of Applied Biosciences, vol. 26, pp. 1594-1602, 2010.

[24] W. Yan and N. A. Tinker, "Biplot analysis of multi-environment trial data: principles and applications," Canadian Journal of Plant Science, vol. 86, no. 3, pp. 623-645, 2006.

[25] T. R. A. de Oliveira, G. d. A. Gravina, G. H. F. de Oliveira et al., "The GT biplot analysis of green bean traits," Ciência Rural, vol. 48, no. 6, pp. 1-6, 2018.

[26] W. Yan and J. Frégeau-reid, "Genotype by yield * trait (GYT) Biplot: a novel approach for genotype selection based on multiple traits," Scientific Reports, vol. 8, 2018.

[27] M. Kaplan, K. Kokten, and M. Akcura, "Assessment of genotype $\times$ trait $\times$ environment interactions of silage maize genotypes through GGE Biplot," Chilean Journal of Agriculrtural Research, vol. 77, no. 3, pp. 212-217, 2017.

[28] O. O. Aina, A. G. O. Dixon, and E. A. Akinrinde, "Trait association and path analysis for cassava genotypes in four agroecological zones of Nigeria," Journal of Biological Sciences, vol. 7, pp. 759-764, 2007.

[29] E. J. de Oliveira, S. d. T. Aidar, C. V. Morgante, A. R. d. M. Chaves, J. L. Cruz, and M. A. Coelho Filho, "Genetic parameters for drought-tolerance in cassava," Pesquisa Agropecuária Brasileira, vol. 50, no. 3, pp. 233-241, 2015.

[30] L. O. Omoigui, M. F. Ishiyaku, A. Y. Kamara, and S. O. Alabi, "Genetic variability and heritability studies of some reproductive traits in cowpea (Vigna unguiculata (L.) Walp.)," African Journal of Biotechnology, vol. 5, no. 13, pp. 1191-1195, 2006.

[31] M. D. Clark and E. Watkins, "Broad-sense heritability estimates of turfgrass performance characteristics in Native Prairie junegrass germplasm," HortScience, vol. 47, no. 9, pp. 1228-1233, 2012.

[32] K. E. Kenworthy, C. M. Taliaferro, B. F. Carver, D. L. Martin, J. A. Anderson, and G. E. Bell, "Genetic variation in Cynodon transvaalensis Burtt-davy," Crop Science, vol. 46, no. 6, pp. 2376-2381, 2006.

[33] H. Şeker, A. Yazici, and P. Uysal, "Analysis of variability, heritability, and genetic advance in seed yield and related traits of orchardgrass (Dactylis glomerata L.) populations," Turkish Journal of Agriculture and Forestry, vol. 38, pp. 633-643, 2014.

[34] I. H. Delacy, B. Skovmand, and J. Huerta, "Characterization of Mexican wheat landraces using agronomically useful attributes," Genetic Resources and Crop Evolution, vol. 47, no. 6, pp. 591-602, 2000.

[35] W. Yan and M. S. Kang, GGE Biplot Analysis: A Graphical Tool for Breeders, Geneticists, and Agronomists, CRC Press, Boca Raton, FL, USA, 2003.

[36] P. Monneveux, D. A. Ramírez, and M. T. Pino, "Drought tolerance in potato ( $S$. tuberosum L.) can we learn from drought tolerance research in cereals?" Plant Science, vol. 205206, pp. 76-86, 2013.

[37] EPA, National Action Programme to Combat Drought and Desertification, Environmental Protection Agency, Washington, DC, USA, 2003.

[38] I. J. Ekanayake, Cassava Procedures for Growth Analysis, IITA, Ibadan, Nigeria, 1996.

[39] Decagon, Leaf Porometer Operator's Manual, Decagon Devices, Inc., Pullman, WA, USA, 2008.
[40] W. Msikita, B. James, E. Nnodu, J. Legg, K. Wydra, and F. Ogbe, Disease Control in Cassava Farms, IITA, Ibadan, Nigeria, 2000.

[41] SAS, SAS Proprietary Software, SAS Institute, Inc., Cary, NC, USA, 2009.

[42] K. Singh and B. Chaudhary, Biometrical Methods in Quantitative Genetic Analysis, Kalyani Publishers/Lyall Bk Depot, Faisalabad, Pakistan, 1979.

[43] R Core Team, R: A Language and Environment for Statistical Computing, R Foundation for Statistical Computing, Vienna, Austria, 2018.

[44] W. Esuma, R. S. Kawuki, L. Herselman, and M. T. Labuschagne, "Stability and genotype by environment interaction of provitamin A carotenoid and dry matter content in cassava in Uganda," Breeding Science, vol. 66, no. 3, pp. 434-443, 2016.

[45] A. A. C. Alves, "Cassava botany and physiology," in Cassava Biology Production and Utilisation, R. J. Hillocks, J. M. Thresh, and A. Bellotti, Eds., pp. 67-89, CABI Publishing, Wallingford, UK, 2002.

[46] E. Okogbenin, I. J. Ekanayake, and M. C. M. Porto, "Genotypic variability in adaptation responses of selected clones of cassava to drought stress in the Sudan Savannah Zone of Nigeria," Journal of Agronomy and Crop Science, vol. 189, no. 6, pp. 376-389, 2003.

[47] M. A. El-Sharkawy, A. Hernández, and C. Hershey, "Yield stability of cassava during prolonged mid-season water stress," Experimental Agriculture, vol. 28, no. 2, pp. 165-174, 1992.

[48] S. M. de Tafur, M. A. El-Sharkawy, and F. Calle, "Photosynthesis and yield performance of cassava in seasonally dry and semiarid environments," Photosynthetica, vol. 33, no. 2, pp. 249-257, 1998.

[49] D. S. Falconer and T. F. C. Mackay, Introduction to Quantitative Genetics, Longman, Harlow, UK, 4th edition, 1996.

[50] A. G. O. Dixon and E. N. Nukenine, "Genotype x environment interaction and optimum resource allocation for yield and yield components of cassava," African Crop Science Journal, vol. 8, 2000.

[51] M. Marlosetti, J.-M. Ribaut, and F. A. van Eeuwijk, "The statistical analysis of multi-environment data: modelling genotype-by-environment interaction and its genetic basis," Frontiers in Physiology, vol. 4, no. 44, pp. 1-17, 2013.

[52] H. G. Gauch, "Statistical analysis of yield trials by AMMI and GGE,” Crop Science, vol. 46, pp. 1488-1500, 2006.

[53] S. Ceccarelli, "Adaptation to low/high input cultivation," Euphytica, vol. 92, no. 1-2, pp. 203-214, 1996.

[54] I. Aspiazú, T. Sediyama, J. I. Ribeiro Jr. et al., "Photosynthetic activity of cassava plants under weed competition," Planta Daninha, vol. 28, pp. 963-968, 2010.

[55] M. P. Reynolds, "Physiological approaches to wheat breeding," in Bread Wheat Improvement and Production, B. C. Curtis, S. Rajaram, and H. G. Macpherson, Eds., pp. 119-140, Rome, Italy, 30th edition, 2002.

[56] J. J. Olivares-Villegas, M. P. Reynolds, and G. K. McDonald, "Drought-adaptive attributes in the Seri/Babax hexaploid wheat population," Functional Plant Biology, vol. 34, no. 3, pp. 189-203, 2007.

[57] M. A. El-Sharkawy, S. M. De Tafur, and L. F. Cadavid, "Potential photosynthesis of cassava as affected by growth conditions," Crop Science, vol. 32, pp. 1336-1342, 1992.

[58] M. R. Rivero, M. Kojima, A. Gepstein et al., "Delayed leaf senescence induces extreme drought tolerance in a flowering 
plant," The Proceedings of the National Academy of Science, vol. 104, no. 49, pp. 19631-19636, 2007.

[59] J. Adjebeng-Danquah, J. Manu-Aduening, V. Gracen, S. K. Offei, and I. K. Asante, "Genotypic variation in abscisic acid content, carbon isotope ratio and their relationship with cassava growth and yield under moisture stress and irrigation," Journal of Crop Science and Biotechnology, vol. 19, no. 4, pp. 263-273, 2016.

[60] L. O. Duque and T. L. Setter, "Cassava response to water deficit in deep pots: root and shoot growth, ABA, and carbohydrate reserves in stems, leaves and storage roots," Tropical Plant Biology, vol. 6, pp. 199-209, 2013.

[61] A. S. Oladejo, R. O. Akinwale, I. O. Obisesan, and I. Ife, "Interrelationships between grain yield and other physiological traits of cowpea cultivars," African Crop Science Journal, vol. 19, no. 3, pp. 189-200, 2011.

[62] J. R. Pardales and A. Yamauchi, "Regulation of root development in sweetpotato and cassava by soil moisture during their establishment period," Plant and Soil, vol. 255, pp. 201-208, 2003.

[63] P. Sharifi and A. A. Ebadi, "Relationships of rice yield and quality based on genotype by trait (GT) biplot," Annals of the Brazilian Academy of Sciences, vol. 90, no. 1, pp. 343-356, 2018.

[64] E. Farshadfar and P. Elyasi, "Screening quantitative indicators of drought tolerance in bread wheat (Triticum aestivum L.) landraces," European Journal of Experimental Biology, vol. 2, no. 3, pp. 577-584, 2012.

[65] E. Farshadfar, M. M. Poursiahbidi, and A. R. Pour, "Repeatability of drought tolerance indices in bread wheat genotypes," International Journal of Agriculture and Crop Sciences, vol. 4, no. 13, pp. 891-903, 2012.

[66] E. Tsegaye, N. Dechassa, and E. V. D. Sastry, "Genetic variability for yield and other agronomic traits in sweet potato," Journal of Agronomy, vol. 6, no. 1, pp. 94-99, 2007.

[67] M. B. Tewodros, "Genetic diversity of aerial yam (Dioscorea bulbifera L.) accessions in Ethiopia based on agronomic traits," Agriculture, Forestry and Fisheries, vol. 2, no. 2, pp. 67-72, 2013.

[68] B. B. Peprah, E. Parkes, J. Manu-Aduening, P. Kulakow, A. van Biljon, and M. Labuschagne, "Genetic variability, stability and heritability for quality and yield characteristics in provitamin A cassava varieties," Euphytica, vol. 216, no. 2, pp. 1-13, 2020.

[69] T. Sabesan, R. Suresh, and K. Saravanan, "Genetic variability and correlation for yield and grain quality characters of rice grown in coastal saline low land of Tamil Nadu," Electronic Journal of Plant Breeding, vol. 1, no. 1, pp. 56-59, 2009. 